\title{
The Commerce Clause and Federalism after Lopez and Morrison: The Case for Closing the Jurisdictional-Element Loophole
}

\author{
Diane McGimsey†
}

TABLE OF CONTENTS

Introduction

I. Federalism: The Principle at Stake in Lopez and Morrison ............ 1682

II. How a State-Line Crossing Became Sufficient to Invoke the Commerce Clause Power

A. Substantial-Effects Prong 1689

B. Regulation of the Channels and Instrumentalities of Interstate Commerce.

1. Instrumentalities of Interstate Commerce ........................... 1692

2. Channels of Interstate Commerce ........................................ 1696

3. The Jurisdictional Element................................................... 1699

III. Lopez and Morrison: How the Apparent "Revolution" in Congress's Commerce Clause Power Left that Power Essentially Intact

IV. The Jurisdictional Element and Federalism: Why the Commerce Clause Still Needs Revisiting ....................................................... 1706

A. Implications of the Growth of the U.S. Economy ...................... 1706

B. Lower Court Decisions ............................................................... 1710

1. Federal Carjacking Statute ................................................. 1710

2. Felon-in-Possession Statute............................................... 1712

3. Federal Arson Statute ........................................................... 1714

4. Child Support Recovery Act ................................................ 1716

Copyright $@ 2002$ California Law Review, lnc. California Law Review, Inc. (CLR) is a California nonprofit corporation. CLR and the authors are solely responsible for the content of their publications.

$\uparrow \quad$ Law clerk to the Honorable J. Harvie Wilkinson III, Chief Judge, U.S. Court of Appeals for the Fourth Circuit; J.D., School of Law, University of California, Berkeley (Boalt Hall), 2002; B.A., Claremont McKenna College, 1999. The author is especially grateful to Professor John C. Yoo for his immeasurable assistance and support and to Professor Robert Post for teaching her constitutional law. Thank you also to Sarah Shaw and Heather Rosmarin of the California Law Review for their careful editing, and to my family and friends, especially Alex McGimsey, Michelle Goncalves, Stella Ho, David Brown, and Sarah Ratcliffe for their support. 


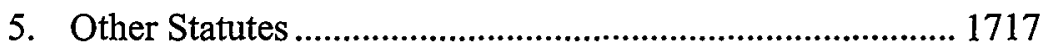

V. Reworking the Jurisdictional Element .............................................. 1719

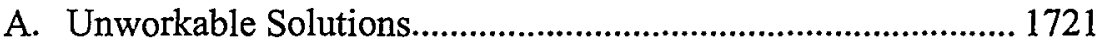

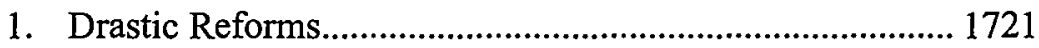

2. Time-Nexus Requirement ................................................. 1726

3. Commerce-Nexus Requirement ...................................... 1728

4. Causation-Nexus Requirement.......................................... 1730

B. A Workable Solution: A Purpose-Nexus Requirement ........... 1731

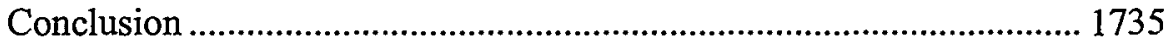




\title{
The Commerce Clause and Federalism after Lopez and Morrison: The Case for Closing the Jurisdictional-Element Loophole
}

\author{
Diane McGimsey
}

\section{INTRODUCTION}

In 1995, for the first time in almost sixty years, the Supreme Court struck down a federal statute as exceeding Congress's Commerce Clause power. ${ }^{1}$ Numerous commentators viewed United States $v$. Lopez as an indicator that a revolution in Commerce Clause jurisprudence was imminent, a revolution with potentially enormous implications for the relationship between the federal government and the states. ${ }^{2}$

This initial response to Lopez was understandable. In the prior two decades the Court had decided at least eleven cases validating Congress's power to regulate under the Commerce Clause. ${ }^{3}$ Moreover, in the years since 1937, Congress had used its Commerce Clause power to regulate nearly everything, from a single farmer's growth of wheat for home consumption $^{4}$ to the activities of a mom-and-pop restaurant located eleven blocks from the nearest interstate highway and employing only thirty-six

1. See United States v. Lopez, 514 U.S. 549 (1995) (striking down the Gun-Free School Zones Act).

2. See, e.g., Steven G. Calabresi, A Government of Limited and Enumerated Powers: In Defense of United States v. Lopez, 94 Mrch. L. REv. 752, 752 (1995) (referring to the Lopez decision as "revolutionary and long overdue"); Erwin Chemerinsky, The Federalism Revolution, 31 N.M. L. REv. 7, 30 (2001) (concluding that Lopez, when viewed together with other recent cases, signals a federalism revolution); Linda Greenhouse, Focus on Federal Power, N.Y. Times, May 24, 1995, at A1, B8 (describing Lopez as having helped put into play "fundamental questions about the essential nature of the Federal Government"); Timothy M. Phelps, Judicial Revolution: Recent Cases Slant Towards States, NewsDAY, May 29, 1995, at A13 (calling the Lopez decision an indication of a "revolutionary states-rights movement within the Court").

3. Allied-Bruce Terminix Cos. v. Dobson, 513 U.S. 265 (1995); United States v. Edge Broad. Co., 509 U.S. 418 (1993); Dennis v. Higgins, 498 U.S. 439 (1991); South Carolina v. Baker, 485 U.S. 505 (1988); Transcontinental Gas Pipe Line Corp. v. State Oil \& Gas Bd. of Miss., 474 U.S. 409 (1986); Garcia v. San Antonio Metro. Transit Auth., 469 U.S. 528 (1985); EEOC v. Wyoming, 460 U.S. 226 (1983); New England Power Co. v. New Hampshire, 455 U.S. 331 (1982); Hodel v. Va. Surface Mining \& Reclamation Assoc., 452 U.S. 264 (1981); United Transp. Union v. Long 1sland R.R. Co., 455 U.S. 678 (1982); Fry v. United States, 421 U.S. 542 (1975).

4. Wickard v. Filburn, 317 U.S. 111 (1942) (upholding the Agricultural Adjustment Act of 1938 as applied to a farmer who harvested 239 bushels of wheat over his quota for use on his own farm). 
persons. ${ }^{5}$ However, since the statute at issue in Lopez was relatively minor, ${ }^{6}$ no one could predict if Lopez meant that the Commerce Clause would no longer be, as Judge Alex Kozinski aptly referred to it, the "Hey, youcan-do-whatever-you-feel-like Clause." Then, five years after Lopez, in United States v. Morrison, the Court struck down the Violence Against Women Act's civil remedy provision as beyond Congress's Commerce Clause power. ${ }^{8}$ The Morrison decision seemed to confirm that Lopez was the beginning of a new era of judicial limitation of Congress's Commerce Clause power. ${ }^{9}$

The Court's decisions in Lopez and Morrison have not, however, spurred the revolution initially foreseen by commentators. Predictions that numerous federal statutes would be at risk of judicial invalidation, including statutes criminalizing carjacking and violent demonstrations at abortion clinics, ${ }^{10}$ have not come true. Instead, lower courts have consistently rejected Lopez- and Morrison-based challenges to Congress's ability to enact statutes under its Commerce Clause power. ${ }^{11}$

5. Katzenbach v. McClung, 379 U.S. 294 (1964) (upholding an application of Title II of the Civil Rights Act of 1964 to Ollie's Barbecue, a small, family-owned restaurant in Birmingham, Alabama).

6. The Gun-Free School Zones Act ("GFSZA") did little to change the ability of gun owners to travel with firearms into school zones, as forty-three states already had similar statutes. Charles J. Russo, Commentary, United States v. Lopez and the Demise of the Gun Free School Zones Act: Legislative Over-Reaching or Judicial Nit-Picking?, 99 EDUC. L. REP. 11, 22 (1995).

7. Judge Alex Kozinski, Introduction to Volume Nineteen, 19 HARv. J.L. \& Pub. PoL'Y 1, 5 (1995); see also Andrew St. Laurent, Reconstituting United States v. Lopez: Another Look at Federal Criminal Law, 31 Colum. J.L. \& Soc. ProBs. 61, 61 (1997) (suggesting that Judge Kozinski's asscssment no longer applied after Lopez).

8. 529 U.S. 598 (2000). The civil remedy provision of the Violence Against Women Act ("VAWA") provided a civil remedy for "a crime of violence motivated by gender." See 42 U.S.C. $\S 13981$ (1994).

9. See John S. Baker, Jr., United States v. Morrison and Other Arguments Against Federal "Hate Crime" Legislation, 80 B.U. L. REv. 1191,1192 (2000) (noting that before Morrison many courts and commentators were skeptical about the Court's dedication to enforcing fedcralism limits, but that the Court's decision in Morrison reconfirmed that commitment); Jesse H. Choper \& John C. Yoo, The Scope of the Commercc Clause after Morrison, 25 OKLA. CiTY U. L. REv. 843, 852 (2000) (concluding that the Supreme Court's decision in Morrison signaled that Lopez was not simply an aberration); Ronald D. Rotunda, The New States' Rights, the New Federalism, the New Commerce Clause, and the Proposed New Abdication, 25 OKLA. CiTy. U. L. Rev. 869, 916 (2000) (argning that even if one does not think Lopez was of great import, Morrison serves as proof that the Court indeed was serious in Lopez).

10. See, e.g., Linda Greenhouse, High Court Puts Dent in Congress' Authority, ARIz. RepuB., Apr. 27, 1995, at A1.

11. For a discussion of lower court decisions, see infra Part IV.B. For the view that the Court will fail to enforce the limits it set in Lopez and Morrison, see Suzanna Sherry, The Barking Dog, 46 CASE W. RES. L. REv. 877, 877 (1996) ("I believe that Lopez will join a growing list of cases that have been a nine-day wonder: cases that appear to be startling changes in direction and therefore create great joy and consternation when first decided, but that are subsequently ignored by the Court."); see also Larry Kramer, What's a Constitution for Anyway? Of History and Theory, Bruce Ackerman and the New Deal, 46 CASE W. REs. L. REv. 885, 885 (1996) ("Sober second thoughts have been, well, sober, and many observers now say that Lopez may not be such a big deal after all."). 
A primary reason why Lopez and Morrison did not spur a revolution is that they limited congressional power with respect to only one of three categories of activity that courts have allowed Congress to regulate under the Commerce Clause. While Lopez and Morrison constricted the broadest $^{12}$ of these three categories, which covers activities "that substantially affect interstate commerce,"13 the decisions did not limit the other two areas that Congress can regulate under its Commerce Clause power: the channels of interstate commerce and the instrumentalities of interstate commerce.

Since Lopez and Morrison, commentators have noted the Court's failure to address these other two areas of Commerce Clause regulation and have suggested ways in which the Court might reform its interpretation of the Commerce Clause to protect the federalism principles articulated in Lopez and Morrison. ${ }^{14}$ However, few commentators have focused on the role of the jurisdictional element as a means by which Congress can continue to carry on its activities as if Lopez and Morrison had never been decided. A jurisdictional-element requirement in a statute purportedly ensures a nexus between the regulated activity and interstate commerce. ${ }^{15}$ The jurisdictional element usually requires that some person or good that is subject to the regulation is either "in or affecting interstate commerce."16 Sometimes the jurisdictional element explicitly requires the transportation of a person or good across state lines im connection with the regulated activity. ${ }^{17}$ Often, however, the jurisdictional element has been interpreted to require only that the person or good subject to the regulation, or perhaps even just a person or good related to the regulated person or good, has

12. See Choper \& Yoo, supra note 9, at 850.

13. Lopez, 514 U.S. at 559; see also infra Part III. In addition, Lopez and Morrison might have denied Congress the ability to regulate in some substantive areas. Choper \& Yoo, supra note 9, at 853. The Court in Morrison notes that punishing intrastate violence "not directed at the instrumentalities, channels, or goods involved in interstate commerce" has always been a power reserved to the states. Morrison, 529 U.S. at 618 . The Court went on to deny a general, plenary police power to the national government. Id. Thus, the Court appears to be saying that there are certain areas that Congress simply cannot regulate. However, the Court has not specifically enumerated such areas.

14. Raoul Berger, Judicial Manipulation of the Commerce Clause, 74 TEx. L. Rev. 695 (1996) (advocating a complete overhaul of the Court's Commerce Clause jurisprudence by rerooting Congress's power in an original understanding of the Commerce Clause); Richard A. Epstein, The Proper Scope of the Commerce Power, 73 VA. L. Rev. 1387 (1987) (same); Donald H. Regan, How to Think About the Federal Commerce Power and Incidentally Rewrite United States v. Lopez, $94 \mathrm{MrCH}$. L. REv. 554 (1995) (suggesting that the Court should get rid of the three prongs altogether and use a less formalistic approach). For a more detailed discussion of these proposals, see infra Part V.A.I.

15. See Lopez, 514 U.S. at 561-62.

16. E.g., 18 U.S.C. $\$ 922(\mathrm{~g})(9)$ (2000) ("It shall be unlawful for any person who has been convicted in any court of a misdemeanor crime of domestic violence... [to] possess im or affecting commerce, any firearm or ammunition which has been shipped or transported in interstate or foreign commerce.").

17. E.g., I8 U.S.C. $\$ 922$ (a) (2) (2000) ("It shall be unlawful for any importer, manufacturer, dealer, or collector licensed nnder the provisions of this chapter [18 U.S.C. $\$ \$ 921-930]$ to ship or transport in interstate or foreign commerce...."). 
crossed a state line at some point. ${ }^{18}$ In sum, the jurisdictional element, which is supposed to connect the regulated person, good, or activity to interstate commerce, can be easily satisfied by a simple state-line crossing, however remote in time or purpose.

The significance of the jurisdictional element is that its presence in a statute leads courts to be lenient. When a statute includes a jurisdictional element, courts usually analyze the statute under Congress's power to protect the channels and instrumentalities of interstate commerce ${ }^{19}$ rather than under Congress's power to regnlate purely intrastate activities that have "substantial effects" on interstate commerce. ${ }^{20}$ As noted above, Lopez and Morrison tightened up the substantial-effects analysis but did not reach the channels and instrumentalities analyses, under which courts typically validate Congress's sweeping interpretation of its Commerce Clause power. Thus, despite the limitations on certain aspects of Congress's Commerce Clause power imposed by Lopez and Morrison, Congress can still use the jurisdictional element to regulate almost any person, good, or activity that involves crossing state lines. ${ }^{21}$ Because courts do not subject statutes containing a jurisdictional element to the stricter "substantial effects" standard of review, Congress's Commerce Clause power remains essentially unchanged after Lopez and Morrison.

The problem with this status quo is that a state-line crossing requirement does not impose meaningful limits on congressional regnlation. One hundred years ago, the fact that a person or good crossed state lines was a more reliable indication of a meaningful connection to interstate commerce because there were fewer noncommercial reasons and opportunities for such line crossing. Today, however, with the vastly increased integration of our society, almost every person or good will, at some point, cross a state line. Consequently, the fact that a person or good has crossed a state line at some point establishes no particular connection to interstate commerce and, thus, no commercial justification for federal regulation.

In recent years, the Rehnquist Court, which has devoted much attention to the federalism issue, ${ }^{22}$ has invalidated various statutes for being inconsistent with its vision of the proper boundaries between the federal

18. E.g., United States v. Johnson, 22 F.3d 106, $108-09$ (6th Cir. 1994). The statute at issue in Johnson criminalized the taking of a motor vehicle "that has been transported, shipped, or received in interstate or foreign commerce." 18 U.S.C. 2119 (2002).

19. See United States v. Robertson, 514 U.S. 669, 671 (1995).

20. See United States v. Williams, 121 F.3d 615,619 (11th Cir. 1997).

21. See Morrison, 529 U.S. at 613; Lopez, 514 U.S. at 561-62.

22. See Choper \& Yoo, supra note 9, at 844 ("Federalism has become the defining issue of the Rehnquist Court."). Despite the Court's previous commitment to federalism, it is unclear now how large a role federalism will play in Chief Justice Rehnquist's later years on the Court given the nationalist sentiments currently sweeping over the United States in response to the September 11 terrorist attacks. 
government and the states. ${ }^{23}$ This Comment argues that the federalism principles underlying those decisions are not likely to endure if the Court does not develop a new approach to reviewing legislation that relies on a jurisdictional element as its only connection to interstate commerce. ${ }^{24}$ Specifically, this Comment will demonstrate that the jurisdictional element in its current form allows Congress to reach almost any sector of society and, therefore, no longer evidences a close enough nexus to interstate commerce to justify a presumption of constitutionality. This paper will propose that the Court liinit Congress's use of the jurisdictional element by imposing a "purpose nexus" requirement. A purpose-nexus requirement would require the jurisdictional element to conform both to the purposes of the statute and the purposes underlying the Commerce Clause power itself.

The next Part briefiy presents some of the main justifications for protecting the integrity of our federalist system, even in inodern times. Part II reviews the development of each of the three rationales that support congressional power to regulate nnder the Commerce Clause: the substantialeffects prong, the instrumentalities-of-commerce prong, and the channelsof-interstate commerce prong. Specifically, Part II analyzes how state-line crossing emerged as sufficient to invoke the Commerce Clause power and how courts caine to apply the channels and instrumentalities prongs to statutes incorporating a jurisdictional elenent. Part III shows how Lopez and Morrison failed to limit Congress's ability to regulate intrastate activities because they failed to address Congress's use of the jurisdictional eleinent as a means to extend its regulatory reach.

Part IV begins by considering how the significance of a state-line crossing as a ineaningful indicator of interstate commerce has diminished as the U.S. econoiny grows. Part IV then examines how lower federal courts have responded to challenges to Congress's Commerce Clause power since Lopez. This examination demonstrates how courts have interpreted the jurisdictional element to implicate the channels and instrumentalities prongs and then have relied on state-line crossings that evince only remote connections to interstate commerce to sustain the constitutionality

23. See, e.g., Bd. of Tr. of the Univ. of Ala. v. Garrett, 531 U.S. 356 (2001) (finding portions of the ADA violative of the Eleventh Amendment); Morrison, 529 U.S. 598; Kimel v. F1. Bd. of Regents, 528 U.S. 672 (2000) (invalidating Congress's attempt to abrogate state sovereign immunity under the ADEA); Alden v. Maine, 527 U.S. 706 (1999) (holding that Congress does not have the power under Article I to abrogate state sovereign immunity); Coll. Sav. Bank v. Fl. Prepaid Postsecondary Educ. Expense Bd., 527 U.S. 666 (1999) (holding that Congress could not abrogate state sovereign immunity under the Trademark Remedy Clarification Act); Lopez, 514 U.S. 549; see also Seth F. Kreimer, Federalism and Freedom, 574 ANnAls AMER. Soc. Pol. \& Soc. Scr. 66, 67 (2001) (noting that the Court's invalidation of federal statues has come at a rate unsurpassed since the Court's reaction agamst the New Deal in 1935-36).

24. Of course, even if the jurisdictional element is revised to impose more meaningful limits on Congress's Commerce Clause power, federalisin may still be threatened by other alternative avenues of federal regnlation. See Choper \& Yoo, supra note 9, at 854-60 (discussing the Spending Clause as an "effective and pervasive alternative method for federal regulation," $i d$. at 855 ). 
of federal statutes. Finally, Part IV shows how such loose interpretations of the jurisdictional element lead to absurd results and undermine federalism principles.

Part V critiques several proposals for reform. First, it briefly reviews drastic solutions that have been proposed by certain commentators. Next, it discusses some obvious potential remedies to limit the jurisdictional element and explains why those remedies will fail. Finally, it proposes that the Court impose a purpose nexus on top of the jurisdictional element in order to ensure that courts adequately police the boundaries of Congress's Commerce Clause power.

\section{I}

\section{Federalism: The Principle at Stake in LOPEZ and MORRISON}

To understand the significance of the Court's failure in Lopez and Morrison to close the jurisdictional-element loophole, it is necessary to consider the importance of federalism in the United States. This Part does not attempt a comprehensive explanation of the benefits of federalism. Rather, the following brief discussion is intended to provide readers with insight into why the Framers considered federalism such an important principle and why it still deserves protection.

Federalism is a dual system of government in which two sovereigns have different, although at times overlapping, powers. ${ }^{25}$ The Constitution clearly gives the federal government exclusive control over certain areas, such as the military and foreign affairs, while explicitly reserving other, unenumerated powers to the states. ${ }^{26}$ Thus, historically the states have had exclusive control over such areas as crime, education, and family law. ${ }^{27}$ The purpose of this explicit enumeration is obvious. The Framers intended the enumeration of powers to serve as a limit on federal governmental power. ${ }^{28}$ Lopez and Morrison both reflect the Court's concern with the proper balance of power between the federal government and the states.

Though skeptics may doubt its relevance to today's nationalized economy and society, ${ }^{29}$ federalism has always been an essential part of the framework that ensures the proper functioning of our system of

25. See generally Harry N. Scheiber, Federalism and the Constitution: The Original Understanding, in AMERICAN LAW AND THE CONSTITUTIONAL ORDER (Lawrence M. Friedman \& Harry N. Scheiber eds., 1988).

26. See id.; see also U.S. ConsT. amend. X.

27. See Choper \& Yoo, supra note 9, at 846 .

28. Thus, some of the Framers saw no nced to include a bill of rights, as they felt the structure of the Constitution adequately protected liberty. See THE FEDERALIST No. 84, at 535 (Alexander Hamilton) (Benjamin Fletcher Wright ed., 1961) ("[W]hy declare that things shall not be done which there is no power to do?").

29. See, e.g., Mark Tushnet, Comment, What Then Is the American?, 38 ARIz. L. Rev. 873, 87679 (1996) (arguing that Americans in general have become more alike, lessening the need for federalism). 
government. The increasing nationalization of certain aspects of society in the United States demands that the question of federalism and its proper boundaries be carefully considered. At each stage of national growth and integration, maintaining the proper federalism boundaries becomes more, not less, important lest the protections inherent in the federalism principles risk dilution, or worse yet, vanish altogether. ${ }^{30}$

Admittedly, pure principle did not alone drive the incorporation of federalism in the Constitution: the hardball politics of the founding period also played a role. ${ }^{31}$ However, protecting federalism does far more than to ensure devotion to the political compromises that produced the Constitution. ${ }^{32}$ First, federalism protects liberty. ${ }^{33} \mathrm{~A}$ dual system of government protects liberty better than a single systein of government because citizens can look to one government to protect its rights from encroachment by the other. ${ }^{34}$ As James Madison observed, federalism protects liberty because it gives the people a double security: "The different governments will control each other at the same time that each will be controlled by itself." ${ }^{35}$ Even Alexander Hamilton, one of the greatest proponents of national power during the founding era, acknowledged the need for a diffusion of power between the state and federal governments. "If citizens' rights are invaded by either, they can make use of the other as an instrument of redress ... . State governments will, in all possible contingencies, afford complete security against invasions of the public liberty by the national authority. "36 Moreover, a dual system of government can also provide more expansive substantive rights than a single system of government. ${ }^{37}$

In addition to protecting liberty, federalism also protects diversity. ${ }^{38} \mathrm{In}$ spite of the increasing nationalization of the economy and society, the United States remams a haven for diverse ideas, cultures, and values. A specific policy, while desirable $\dot{n}_{1}$ one area of the country, might be

30. Woodrow Wilson once noted that federalism "is a question of growth, and every successive state of our political and economic development gives it a new aspect, and makes it a new question." See Marcia Coyle, Washington Gets Amendment Fever, NAT'L L.J., June 5, 1995, at A1.

31. See Choper \& Yoo, supra note 9, at 846.

32. See John C. Yoo, The Judicial Safeguards of Federalism, 70 S. CAL. L. REv. 1311, 1402-04 (1997); see generally Larry Kramer, Understanding Federalism, 47 VAND. L. Rev. 1485 (1994).

33. Atascadero State Hosp. v. Scanlon, 473 U.S. 234, 242 (1985).

34. See The Federalist No. 51, at 323 (James Madison) (Clinton Rossiter ed., 1961).

35. Id.

36. ThE FEDERALIST No. 28, at 181 (Alexander Hamilton) (Clinton Rossiter ed., 1961).

37. See Kreimer, supra note 23 , at 67,70 (pointing out that some states, such as California, which legalized the use of marijuana for medicinal purposes, and Oregon, which legalized assisted suicide, provide more individual rights protection than does the federal government in these areas).

38. See generally Michael M. McConnell, Federalism: Evaluating the Founders' Desigu, $54 \mathrm{U}$. CHI. L. Rev. 1484, 1491-1511 (1987) (book review). 
unsuitable or even oppressive in another area. ${ }^{39}$ By allowing different states to choose different policies, more preferences can be satisfied. This diversity rationale is particularly pertinent to the area of criminal law, an area that is experiencing increasing federalization. ${ }^{40}$ The fact that people can agree that an activity is bad and possibly warrants criminalization does not translate into agreement as to what constitutes the most appropriate legislative response. The death penalty provides the most obvious example: everyone condemns murder, but there is nevertheless a vigorous debate over whether the death penalty should be imposed upon convicted murderers. $^{41}$

Finally, federalism enhances democracy. ${ }^{42}$ Smaller units of government encourage participation because citizens perceive a greater ability to exert meaningful influence. ${ }^{43}$ Furthermore, because state and local governments tend to be smaller and are closer to most citizens, it is easier for citizens to hold those elected representatives accountable for their actions. This potential for increased accountability in turn increases the incentives for officials to respond to state and local preferences. ${ }^{44}$

One might ask why, if the government is so clearly structured as a federalist system, does the Supreme Court need to take active steps to protect federalism? Some scholars and jurists, led by Herbert Wechsler and Jesse Choper, concede the virtues of federalism but argue that federalism protections are adequately built into the Constitution. They conclude that Congress and the President, not the federal judiciary, are responsible for policing those boundaries. ${ }^{45}$ However, this political safeguards theory fails

39. For more on this view, see Gregory v. Ashcroft, 501 U.S. 452, 458 (1991) (noting that a federalist structure of government assures that the government is "sensitive to the diverse needs of a heterogeneous society").

40. See Kathleen F. Brickey, Criminal Mischief: The Federalization of American Criminal Law, 46 HASTINGS L.J. 1135, 1138-39 (1995).

41. See, e.g., Neil H. Cogan, The Rules of Everyday Life, 543 ANNals AM. ACAD. Pol. \& Soc. Scl. 97, 101 (1996). Critics of the diversity rationale argue that while it may be applicable in some limited areas, for the most part, and especially with regard to criminal law, public opinion does not differ substantially enough to support the rationale. See Tom Stacy \& Kim Dayton, The Underfederalization of Crime, 6 CORNELl J.L. \& PUB. PoL'Y 247, 279 (1997).

42. Steven G. Calabresi, Federalism and the Rehnquist Court: A Normative Defense, 574 Annals AM. ACad. Pol. \& Soc. Scl. 24, 27 (2001); Phillip B. Heymann \& Mark H. More, The Federal Role in Dealing with Violent Street Crime: Principles, Questions, and Cautions, 543 Annals AM. ACAD. Pol. \& Soc. Scl. 103, 104 (1996).

43. Heymann \& More, supra note 42, at 104.

44. Id. For a detailed discussion of some concrete problems of federalization, see Rory K. Little, Comment, Myths and Principles of Federalization, 46 Hastings L.J. 1029 (1995).

45. This theory is referred to as the "political safeguards" theory. See, e.g., Jesse H. Choper, Judicial Review and the National Political Process 175-93 (1980); Herbert Wechsler, The Political Safeguards of Federalism: The Role of the States in the Composition and Selection of the National Government, 54 Colum. L. Rev. 543, 543-60 (1954). See also Garcia v. San Antonio Metro. Transit Auth., 469 U.S. 528 (1985) (upholding the application of the Fair Labor Standards Act's ninimum wage and overtime requirements as applied to the San Antonio Metropolitan Transit Authority). The Court based its holding, in part, on the notion that the political process effectively 
to adequately protect federalism for several reasons. ${ }^{46}$ First, Congress cannot be trusted to police its own power. ${ }^{47}$ Second, members of Congress often come under intense pressure to disregard the preferences of a majority of their constituents. ${ }^{48}$ Furthermore, simply because a member of Congress is adequately representing his constituents does not ensure that he or she is also protecting the states qua states. ${ }^{49}$ Finally, the political safeguards theory is out of date because the political process itself protects federalism much less than it did when Herbert Wechsler first conceived of the theory..$^{50}$ Because of the easy availability of cloture (which can defeat states' rights filibusters) in the Senate, and because of the one-person-one-vote decisions, which have left state legislatures with less redistricting power over incumbent representatives, the political process has become much less protective of federalism. ${ }^{51}$ Thus, the political safeguards theory overlooks the political realities that govern national politics today. Further, it wrongly assumes that the political power that state and local governments do retain at the national level will be used to protect federalism. ${ }^{52}$

II

\section{How a State-Line Crossing Became Sufficient to Invoke the Commerce Clause Power}

The Constitution authorizes Congress "to regulate Commerce with foreigu Nations, and among the several States, and with the Indian Tribes." ${ }^{53}$ The delegates to the Constitutional Convention agreed that the new national government needed greater commercial power than the

polices federalism boundaries, and thus the federal judiciary need not step in to protect federalism absent extreme circumstances. Id. at 551-54.

46. For a detailed critique of the political safeguards theory, see Yoo, supra note 32 (discussing the history of the political safeguards theory, the Rehnquist Court's recent rejection of that theory, and how an original understanding of the Constitution supports the rejection).

47. See Calabresi, supra note 42 , at 30.

48. See generally Calabresi, supra note 2. One recent example of such pressures involves the debate over campaign finance reform. While many constituents may express a desire for serious reform, Congressmen are faced with the competing priority of trying to gain reelection, which in large part hinges on an ability to raise campaign funds. Some Congressmen might resist restricting their own ability to raise funds if they believe it will make their quests for reelection more difficult. Calabresi, supra note 42, at 30-31. National politicians face an incentive structure that promotes the expansion of national programs much more than it promotes the defense of federalism. Id. at 30. Calabresi notes that expanding national power results im an expansion of the amount of national resources to which Congress has access. Calabresi, supra note 2, at 795-96. This makes constituents happier than knowing their Congressman is vigorously "defending the proper meaning of the commerce power." Calabresi, supra note 42 , at $30-31$.

49. Calabresi, supra note 42 , at $30-31$.

50. Id. at 30 .

51. Id.

52. See id. For example, state and local governments are often put in a difficult position when faced with a choice between their own autonomy to adopt certain public policies and their increasing dependence on federal funding, which is often predicated on states adopting federal programs.

53. U.S. Const. art. I, \$ 8, cl. 3 . 
Articles of Confederation afforded. ${ }^{54}$ This general agreement regarding the need for a commerce power meant, however, that the delegates spent little time debating and articulating what the scope of the power should be..$^{55}$

At the time of the framing, commerce among the states comprised such a small subset of activities and transactions that few real disputes arose over the scope of the term "commerce." To the Framers, "commerce" probably meant business intercourse, trade, or traffic, as opposed to agriculture and manufacturing. ${ }^{57}$ Divining the Framers' understanding of "among the several States" is more difficult, however, because the concept might include intrastate and interstate activities that are intertwined. ${ }^{58}$ Professor Randy Barnett's textual analysis of the Commerce Clause supports a restrictive definition that limits "among the several States" to commerce that is conducted "between people of different states." 59 However, at least one scholar has posited a more expansive definition of the scope of the Commerce Clause power, arguing that the

54. See, e.g., 2 Joseph Story, Commentaries on the Constitution of the United States 505 (1833); Letter from James Madison to George Washington (Apr. 16, 1787), in THE WRITINGs of JAMES MADISON 344-45 (1900-1910) (arguing that the new national government needed undivided authority over areas such as trade and import and export taxes because of the need for uniformity in those areas).

55. See Albert S. Abel, The Commerce Clause in the Constitutional Convention and in Contemporary Comment, 25 MINN. L. REv. 432, 446. For a general discussion of the original meaning of the commerce power, see Randy E. Barnett, The Original Meaning of the Commerce Clause, $68 \mathrm{U}$. CHI. L. REv. 101 (2001); Grant S. Nelson \& Robert J. Pushaw, Jr., Rethinking the Commerce Clause: Applying First Principles to Uphold Federal Commercial Regulations but Preserve State Control Over Social Issues, 85 IowA L. REv. 1, 13-50 (1999).

56. See infra Part IV.A.

57. See Berger, supra note 14, at 702 (citing SAMuel Johnson, Dictionary of the ENGlish Language (1755)); see also 1 The Records of the Federal Convention of 1787, at 357 (Max Farrand ed., rev. ed. 1966) (suggesting that the early definition of "commerce" was understood to exclude agriculture); ThE Federalist No. 17, at 118 (Alexander Hamilton) (Clinton Rossiter, ed., 1961) ("[T]he supervision of agriculture and of other concerns of a similar nature . . which are proper to be provided for by local legislation, can never be desirable cares of a general jurisdiction.").

58. See Lino A. Graglia, United States v. Lopez: Judicial Review Under the Commerce Clause, 74 TEx. L. REv. 719, 728 (1996). Professor Graglia contends that activities that are themselves intrastate commerce are often also facets of interstate commerce.

59. See Barnett, supra note 55, at 132. Barnett notes several points in support of this definition. First, if "among the several States" included wholly intrastate activity between people of the same state, the phrase would be superfluous. See id. Second, Barnett pointed to the Federalist papers, where James Madison clarified that the purpose of the power was to control and regulate trade between people of different states, motivated by the fear that states might levy improper taxes on goods from other states. See id. (citing The Federalist No. 42, at 90 (James Madison) (Clinton Rossiter ed., 1961)). Finally, Barnett found support for his interpretation in the ratification debates, arguing that the southern states would have never ratified the Constitution if the commerce power included the power to reach solely intrastate activities, specifically the slave trade within a particular state. See id. at 134. See also Berger, supra note 14, at 703-06. Berger adopted a restrictive definition of "among the several States," arguing that "among" is synonymous with "between." 
meaning of "among the states" includes all commerce within any one state. $^{60}$

It is noteworthy that regardless of whether a restrictive or expansive definition of "ainong the several States" is endorsed, neither interpretation supports a definition of the Commerce Clause power that allows Congress to regulate any person or good that has ever crossed a state line. After all, it is hard to argue that a man, out for an afternoon stroll, who walks across the state line from Nevada into California, has anything at all to do with interstate or intrastate commerce. To put it more concretely, even scholars who support expansive definitions for "among the several States" must still contend with the commerce connection.

The tension between a restrictive and expansive interpretation of the Commerce Clause power was also present in Chief Justice Marshall's opinion in Gibbons v. Ogden, ${ }^{61}$ the first and arguably the most important interpretation of the scope of the Commerce Clause. ${ }^{62}$ Some scholars and jurists cite Gibbons to support the argument that Congress's Commerce Clause power is a "plenary" power with very few limitations. ${ }^{63}$ Justice Marshall wrote that the power to regulate interstate commerce "is complete in itself, may be exercised to its utmost extent, and acknowledges no limitations, other than those prescribed in the Constitution." ${ }^{964}$ In contrast, scholars and jurists adhering to a more restrictive interpretation of Congress's Commerce Clause power find support in other portions of Chief Justice Marshall's opmion, ${ }^{65}$ where he highlights the fact that the Constitution is a written constitution with limited, enumerated powers. "The enumeration presupposes soinething not enumerated; and that something, if we regard the language or the subject of the sentence, must be the exclusively internal commerce of a state." $" 66$

Under one reading of Gibbons, ${ }^{67}$ the unrestricted use of the jurisdictional element falls sufficiently within Congress's Commerce Clause power to justify regulations based on even the remotest connections to

60. See, e.g., William Winslow Crosskey, I Politics AND THE CONSTITUTION IN THE HistoRY OF THE UNITED STATES 50-83 (1953).

61. Gibbons v. Ogden, 22 U.S. (9 Wheat.) l (1824).

62. See Michael J. Klarman, How Great Were the "Great" Marshall Court Decisions, 87 VA. L. Rev. 1111, 1127 (2001); Keith Werhan, Checking Congress and Balancing Federalism: A Lesson from Separation-of-Powers Jurisprudence, 57 WASH. \& LEE L. REv. 1213, 1232 (2000).

63. See, e.g., United States v. Faasse, 265 F.3d 475, 483-84 (6th Cir. 2001); Vicki C. Jackson, Federalism and the Uses and Limits of Law: Printz and Principle?, 111 HARv. L. REv. 2180 n.242 (1998); Michael A. Lawrence, Toward a More Coherent Dormant Commerce Clause: A Proposed Unitary Framework, 21 HARv. J.L. \& PUB. POL'Y 395, 408 (1998).

64. See Gibbons, 22 U.S. at 196.

65. See, e.g., Lopez, 514 U.S. at 566; Groves v. Slaughter, 40 U.S. 449 (Mem) (1841); Steven A. Delchin, Viewing the Constitutionality of the Access Act Through the Lens of Federalism, 47 CASE W. REs. L. REv. 553, 562 (1997).

66. Gibbons, 22 U.S. at 194-95.

67. See cases and commentators cited supra note 65. 
interstate commerce. Chief Justice Marshall defined "among" as "intermingled with." Commerce that is "completely internal . . . and which does not extend to or affect other States," is, according to Chief Justice Marshall, outside the scope of Congress's Commerce Clause power. ${ }^{69}$ Chief Justice Marshall also defined "among" as that which concerns more than one state. ${ }^{70}$ Under this latter definition, it is difficult to say that anything is completely internal because, depending on the level at which you examine the activity, "concern" can encompass a broad range of intrastate activities only remotely connected to interstate commerce. Thus, today, almost every person or good could be considered "among" the states in the sense described by Chief Justice Marshall.

However, it is important to emphasize one fact: Gibbons dealt solely with commerce among the states and did not reach purely intrastate activities. $^{71}$ The language in Chief Justice Marshall's opinion might support the regulation of intrastate activities that somehow concern more than one state, but such activities differ siguificantly from wholly intrastate noncommercial activities. ${ }^{72}$ This distinction is important because it shows that Gibbons should not have been used to justify unwarranted and unnecessary regulation of purely intrastate activities by Congress. Yet that is exactly what happened: Gibbons opened the floodgates to Congressional regulation based on an overly expansive interpretation of the Commerce Clause.

1 move now to the development of Commerce Clause jurisprudence after Gibbons. Under each of the three prongs-substantial effects, channels, and instrumentalities of commerce-Congress's power to regulate expanded throughout the twentieth century. While courts zeroed in on the

68. Gibbons, 22 U.S. at 194.

69. Id. at 195 .

70. Id.

71. Id. at 1. In Gibbons, the New York legislature had granted Robert Livingston and Robert Fulton an exciusive steamboat license to navigate all waters within New York. See id. The liccnses were later assigned to John R. Livingston, who in turn assigned them to Aaron Ogden. Thomas Gibbons, pursuant to a 1793 federal statute, operated a ferry between New York and New Jersey, violating Ogden's exclusive right to navigate those waters. Id. Ogden sued Gibbons in the New York Court of Chancery, and Gibbons claimed that his activities were lawful under the federal statute. Id. The Court of Chancery agreed with Ogden and issued an injunction. Id. After affirmance by New York's highest court, the parties appealed to the Supreme Court. The Supreme Court reversed, upholding the federal law. See id.

72. Another reason it is problematic to rely on Chief Justice Marshall's opinion in Gibbons as a basis for an expansive definition of Congress's Commerce Clause power is that the opinion was much more sweeping than necessary to decide the case. Gibbons involved subject matter likely to fit within even a restrictive definition of Congress's Commerce Clause power. The dispute involved both commercial activity and transportation between two states. Id. Furthcr, Gibbons addressed one of the major problems that the Framers had designed the Commerce Clause to remedy: state legislation that discriminated against other states, hence creating a problem that only the national govemment could address. See Bradley A. Harsch, Brzonkala, Lopez, and the Commerce Clause Canard: A Synthesis of Commerce Clause Jurisprudence, 29 N.M. L. Rev. 321, 331 (1999); Regan, supra note 14, at 573; see also Barnett, supra note 55, at 132. 
substantial-effects prong, which before Lopez seemed to allow the most regulation, it is clear that by the time the Court decided Lopez, each of the prongs was being interpreted broadly enough to support far more legislation than the Framers intended to allow under the Commerce Clause power.

\section{A. Substantial-Effects Prong}

The history of the substantial-effects prong similarly reflects the tension between expansive and restrictive interpretations of Congress's Commerce Clause power. After Gibbons, the Supreme Court did not hear another major Commerce Clause case until 1895, more than seventy years later. ${ }^{73}$ During the intervening decades, the United States' commercial infrastructure dramatically expanded. By 1880 , the twenty-three miles of operable railroad track m existence when Gibbons was decided had expanded to 93,262 miles. $^{74}$ Also during the late 1800 s, Congress began passing more statutes pursuant to its Commerce Clause power. ${ }^{75}$ The Court closely scrutinized those statutes, defining the Commerce Clause power narrowly during the late nineteenth and early twentieth centuries. ${ }^{76}$

According to the Court's newly restrictive definition of the Commerce Clause power, Congress could regulate purely intrastate activities only if there was a direct effect on interstate commerce. The Court admitted the difficulty of determining what is direct and what is indirect, but noted that the activity/condition must "operate proximately-not mediately, remotely, or collaterally-to produce the effect .... [T] [Te extent of the effect bears no logical relation to its character." ${ }^{\text {"77 }}$ Further, the Court drew bright lines between what was purely intrastate and what was interstate. Thus, Congress could not get around proving direct effects by claiming that because an article had previously traveled through interstate commerce it was not "intrastate." law, were purely intrastate and did not have a direct effect on commerce. For instance, the Court determined that there is a distinction between

73. During the period between Gibbons and United States v. E.C. Knight, 156 U.S. 1 (1895), the Court heard predominantly dormant Commerce Clause cases, addressing whether states, absent a federal statute, could enact legislation affecting interstate commerce. For a brief discussion of some of the important cases during that period, see Nelson \& Pushaw, supra note 55, at 64-68.

74. See United States Bureau of the Census, Historical Statistics of the U.S: Colonial Times to I957, at 427 (1960) [hereinafter Historical Statistics].

75. See, e.g., Sherman Antitrust Act of 1890, Ch. 647, $\$ \$ 1-7,26$ Stat. 209 (1890) (current version at 15 U.S.C. $\$ \$ 1-7$ (1994)); Interstate Commerce Act of 1887, Ch. 104, 24 Stat. 379 (1887) (repealed 1978).

76. E.g., Hammer v. Dagenhart, 247 U.S. 251 (1918); E.C. Knight Co., 156 U.S. 1.

77. Carter v. Carter Coal Co., 298 U.S. 238, 307-08 (1936).

78. See, e.g., Schechter Poultry Corp. v. United States, 295 U.S. 495 (1935) (holding that Congress could not regulate the sale of chickens just because they had once been shipped interstateonce they got to their destination, they ceased to be interstate commerce). 
manufacturing and commerce and that the former is always "a matter of local regulation" with no direct effect on interstate commerce. ${ }^{79}$

President Roosevelt's landslide reelection in 1936, coupled with his famous court-packing plan, ${ }^{80}$ and Justice Roberts" "switch in time that saved nine," Commerce Clause power. While Congress was still considering the courtpacking plan, the Court decided National Labor Relations Board v. Jones \& Laughlin Steel Corp. ${ }^{82}$ By a 5-4 margin, the Court sustained the National Labor Relations Act of 1935, a law intended to protect laborers' right to organize by prohibiting employers from discharging employees for engaging in union activity. ${ }^{83}$ In so doing, the Court abandoned its emphasis on bright-line distinctions, such as those between manufacturing and commerce and between direct and indirect effects, and instead introduced a new test. ${ }^{84}$ As long as the regulated activity had a "close and substantial relation to interstate commerce," it did not matter if the statute regulated solely intrastate or local activities. ${ }^{85}$ After Jones \& Laughlin, the Court no longer examined the intrastate activity in question, but rather focused on its effect. $^{86}$

Five years later, the Court expanded the Commerce Clause power even further when it upheld the Agricultural Adjustment Act. ${ }^{87}$ The Agricultural Adjustment Act imposed growth quotas on farmers. Wickard v. Filburn involved a farmer who violated the act's quotas by growing an extra 239 bushels of wheat. ${ }^{88}$ Although the farmer intended to use the extra wheat solely for consumption on his own farm, the Court held that Congress could regulate such activity because it substantially affected interstate commerce. ${ }^{89}$ To reach this conclusion, the Court introduced an

79. Hammer, 247 U.S. at 272.

80. In response to the Court's refusal to uphold much of the aggressive social and economic welfare legislation President Roosevelt tried to pass during the Great Depression, the President introduced his infamous court-packing plan, which would have allowed him to nominate six new Justices to the Supreme Court. See William E. Leuchtenburg, The Supreme Court Reborn: The Constitutional Revolution in the AGe of Roosevelt 132-62 (1995).

81. Philip Bobbitt, Constitutional Fate 39 (1982) (crediting the phrase to Harvard Law School Professor Thomas Reed Powell).

82. 301 U.S. 1 (1937).

83. See id. at $22-23,49$.

84. See, e.g., Victoria Davis, Note, A Landmark Lost: The Anemic Impact of United States v. Lopez on the Federalization of Criminal Law, 75 NEB. L. REv. 117, 122-23 (1996) (discussing the "dramatic shift" in the Court's interpretation of the Commerce Clause power during the 1930s).

85. See 301 U.S. at 37. The Court noted that "the fact that the employees here concerned were engaged in production is not determinative. The question remains as to the effect upon interstate commerce of the labor practice involved." Id. at 40.

86. See id. at 32 ("[I]t is the effect upon commerce, not the source of the injury, which is the criterion."); see also Wickard v. Filburn, 317 U.S. 111, 123-25 (1942).

87. See Wickard, 317 U.S. 111.

88. Id. at $114-15$.

89. Id. at $128-29$. 
aggregation principle that greatly expanded Congress's Commerce Clause power. The Court acknowledged that Wickard's extra growth of wheat did not have a substantial effect on interstate commerce when viewed in isolation, but the Court reasoned that comparable violations by similarly situated farmers would, in the aggregate, substantially affect interstate commerce..$^{90}$ After Wickard, Congress nceded only to show that the regulated activity, when aggregated with other like activities, had a substantial effect on commerce. ${ }^{91}$

Not long after the Court began to expansively interpret the Commerce Clause power, it became difficult to take federalisin review seriously. ${ }^{92}$ The substantial-effects prong set a low bar. Under the prong, the Court simply asked whether Congress had a rational basis to conclude that the activity in question, when aggregated with similar activities, substantially affected commerce. ${ }^{93}$ Such a forgiving standard hardly seems consistent with the Constitution's grant of only limited powers to the federal government. ${ }^{94}$ With such a deferential definition of what substantially affects interstate commerce, it is not surprising that both Congress and the federal courts have paid little attention to the other two prongs of Congress's Commerce Clause power: the channels and the instrumentalities of interstate coinmerce.

\section{B. Regulation of the Channels and Instrumentalities of Interstate} Commerce

Most of the debate over the expansion of Congress's Commerce Clause power has focused on Congress's ability to regulate wholly intrastate activities via the substantial-effects prong. Courts and scholars have paid relatively little attention to Congress's ability to regulate the channels and instrumentalities of commerce. The Court has seemed to take it as a

90. See id. at 127 ("That appellee's own contribution to the demand for wheat may be trivial by itself is not enough to remove him from the scope of the federal regulation where, as here, his contribution, taken together with that of others similarly situated, is far from trivial.").

91. E.g., Katzenbach v. McClung, 379 U.S. 294, $301-03$ (1964).

92. See Graglia, supra note 58 , at 742 .

93. From the aggregation theory, the Court had no choice but to eventually utilize a rational-basis review, because the question of whether an activity, when aggregated with other "like" activities, substantially affects interstate commerce takes place in a hypothetical world. See Delchin, supra note 65, at 590; see, e.g., Perez v. United States, 402 U.S. 146 (1971) (upholdmg the Consumer Credit Protection Act, which criminalized "loan sharking" or "extortionate credit transactions"). The Perez Court found that Congress could have rationally concluded that loan sharking substantially affects interstate commerce because it "exacts millions from the pockets of people, coerces its victims into the commission of crimes against property, and causes the takeover by racketeers of legitimate business." Id. at 156. See also Maryland v. Wirtz, 392 U.S. 183, 195 (1968) (upholding an application of the Fair Labor Standards Act, which regulated the hours and wages of certain employees, based on the fact that the employers involved made purchases from out of state).

94. Ann Althouse, Inside the Federalism Cases: Concern About the Federal Courts, 574 ANNALs AM. ACAD. Pol. \& Soc. Sci. 132, 137 (2001). 
given that Congress's Commerce Clause power should extend to persons, goods, and activities that are deemed to be indisputably interstate because they are somehow connected to the crossing of state lines. ${ }^{95}$

\section{Instrumentalities of Interstate Commerce}

The "instrumentalities of commerce" are generally considered things used in carrying out commerce, such as motor vehicles, roadways, railways, trains, and planes. ${ }^{96}$ However, the definition is broad: forms of communication, such as telephone lines and wires that transmit communications across state lines, are also considered instrumentalities of commerce. ${ }^{97}$ The Court has even included "persons or things in interstate commerce" in the instrumentalities prong of Congress's Commerce Clause power. ${ }^{98}$

During the same years that the Supreme Court was setting forth a restricted view of Congress's Commerce Clause power under the substantialeffects prong, the Court established several bases for congressional regulation of the instrumentalities of commerce. For instance, the Court established that Congress could regulate the instrumentalities of interstate commerce to prevent actors in one state from using those instrumentalities to inflict harm in another. Thus, in Hipolite Egg Co. v. United States, the Court upheld Congress's power to regulate transportation in interstate commerce of adulterated articles that would deceive or injure persons in the receiving state. ${ }^{99}$ Similarly, in James Clark Distilling Co. v. Western Maryland Railway Co., the Court upheld Congress's power to prevent the use of the instruinentalities of interstate commerce to carry intoxicating liquors into any state where they were prohibited. ${ }^{100}$

The power to regulate the instrumentalities of commerce in order to prevent harm among states was not initially unlimited, however. When the harm was not actually accoinplished, at least in part, by using the instrumentalities of interstate commerce, the Court refused to sustain legislation. In Hammer v. Dagenhart, the Court struck down the Act of September 1, 1916, which prohibited the transportation in interstate commerce of goods made at a factory that had employed children under the age of fourteen

95. See Louis J. Virelli III \& David S. Leibowitz, "Federalism Whether They Want it or Not": The New Commerce Clause Doctrine and the Future of Federal Civil Rights Legislation after United States v. Morrison, 3 U. PA. J. ConST. L. 926, 937 (200I).

96. Baldwin v. G.A.F. Seelig, Inc., 294 U.S. 511 , 5 I7 (I935); Seth J. Safra, Note, The Amended Gun-Free School Zones Act: Doubt as to its Constitutional Remains, 50 DuKE L.J. 637, 657 (2000).

97. United States v. Clayton, 108 F.3d I114, 1117 (9th Cir. 1997); Christopher Lieb Nybo, Dialing $M$ for Murder: Assessing the Interstate Commerce Requirement for Federal Murder-for-Hire, 2001 U. ChI. Legal F. 579, 579 n.130.

98. See Lopez, 514 U.S. at 558.

99. 220 U.S. 45,55 (I911).

100. 242 U.S. $311,325-32$ (I917). 
withm thirty days of the shipment of the goods. ${ }^{101}$ The Court emphasized that in prior cases where Congress's power to regulate the instrumentalities of interstate commerce had been upheld, "the use of interstate transportation was necessary to the accomplishment of harmful results." 102 The Court then noted that the harm the act sought to prevent-child labor-had nothing to do with interstate commerce. ${ }^{103}$ It was accomplished regardless of whether the goods were shipped interstate or not. In other words, Congress's purpose im enacting the Act bore no relation to interstate commerce. Thus, the Court also concluded that Congress could not use its Commerce Clause power to achieve a purpose not related to regulating interstate commerce, such as to indirectly control local trade and manufacture, matters properly left with the states. ${ }^{104}$

When the Court overruled Hammer v. Dagenhart in Untied States $v$. Darby, ${ }^{105}$ and thereby eliminated any requirement that the purpose of the legislation relate to the regulation of interstate commerce, the requirement that the channels or the instrumentalities of commerce must be used to accomplish the harm lost much of its punch. Without any other explicit limitation, Congress retained the leeway to punish activities that were remote from the use of the channels or the instrumentalities of interstate commerce. For instance, under this interpretation Congress could still, under its Commerce Clause power, punish any crime in which the perpetrator drove a vehicle (an instrumentality of commerce) to get to the location where he would carry out the crime.

The Court also held that Congress could regulate the instrumentalities of commerce to protect the instrumentalities theinselves, even when regulation of interstate instrumentalities incidentally required regulation of intrastate instrumentalities. In Southern Railway v. United States, ${ }^{106}$ the Court considered legislation that involved the instrumentalities of both imtrastate and interstate commerce. The Safety Appliance Act, premised on the understanding that railroads are instrumentalities of commerce, regulated the safety standards of certain railroad car equipment, regardless of whether those cars traveled interstate or wholly intrastate. ${ }^{107}$ The Court upheld the act based on Congress's plenary power to protect interstate commerce, regardless of whether the danger arose from interstate or intrastate activities. ${ }^{108}$ The Court's decision probably did not spur federalism concerns,

101. 247 U.S. 251, 269, 277 (1918), overruled by United States v. Darby, 312 U.S. 100 (1941). The Court in Darby abandoned the Hammer requirement that the regulated articles must themselves be "harmful or deleterious." Darby, 312 U.S. at 115-17.

102. Hammer, 247 U.S. at 271.

103. See id. at 272.

104. See id. at 273-74.

105. United States v. Darby, 312 U.S. 100 (1941).

106. 222 U.S. 20 (1911).

107. Id. at 24 .

108. Id. at 27. 
however, because reasonable safety concerns necessitated such a broad grant of authority. For instance, Congress could not prevent physical injury on the interstate railways without regulating both intrastate and interstate railway cars because the cars are often intermingled. ${ }^{109}$ The last point is a very important one. Here, because of the intermingling of cars, Congress had no choice but to regulate all of them in order to exercise its power over the safety of the interstate railways. Read narrowly, then, this rationale puts a very strict limitation on the Commerce Clause power, requiring an impossibility of Congress achieving its proper purpose without regulating both intrastate and interstate activity.

Finally, the Court justified Congress's regulation of the instrumentalities of commerce based on the need to prevent economic injury to interstate commerce. In Houston, E. \& W. Tex. Railway Co. v. United States, ${ }^{110}$ the Court considered an order by the Interstate Commerce Commission ("ICC") requiring an interstate railroad to charge the same rates for both intrastate and interstate shipments. The complaint was that the Houston, East \& West Texas Railway Company charged lower rates for shipments out of Dallas and other points in Texas into eastern Texas than they did for shipments that came into Texas from Shreveport, Louisiana. ${ }^{111}$ In upholding the ICC order, the Court recognized one of the purposes underlying the enactment of the Commerce Clause:

Interstate trade was not left to be destroyed or impeded by the rivalries of local governments. The purpose was to make impossible the recurrence of the evils which had overwhelmed the Confederation and to provide the necessary basis of national unity by insuring 'uniformity of regulation against conflicting and discriminating state legislation.' 112

Thus, the Court held that Congress could prevent actors from using the instrumentalities of interstate commerce, which are often also used as instrumentalities of intrastate commerce, to injure interstate commerce. ${ }^{113}$

This power came with a limitation, however. The Court held that Congress's control of the instruments of interstate commerce only extended to

matters having such a close and substantial relation to interstate traffic that the control is essential or appropriate to the security of that traffic, to the efficiency of the interstate service, and to the maintenance of conditions under which interstate commerce may

109. Id.

110. 234 U.S. 342 (1914).

111. See id. at 346. For instance, based on the company's rate scheme, if a shipment commenced in Dallas and went eastward within Texas, 60 cents would buy 160 miles of first class carriage. The same 60 cents, however, would only buy 55 miles of carriage from Shreveport into Texas. Id.

112. Id. at 350 .

113. Id. at 353-54. 
be conducted upon fair terms and without molestation or hindrance. ${ }^{14}$

Thus, the Court implicitly limited Congress's control over the instrumentalities of commerce to those means necessary to carry out the underlying purposes of the Commerce Clause power.

Allowing Congress to exercise control over the instrumentalities of interstate commerce, even when they are also instrumentalities of intrastate commerce, makes sense. If the shipment of goods in interstate commerce requires the use of the instrumentalities of intrastate commerce, Congress must be able to ensure that states are not using control over intrastate instrumentalities to discriminate against goods and products from other states. Howvever, as described above, the Houston Court's expansive view of Congress's Commerce Clause power included a clear articulation of the limits of that power. Mere line crossings were not enough to justify regulation of the instrumentalities of interstate, and consequently, intrastate, commerce. Rather, such regulation could be justified only by legitimate concerns regarding the protection of interstate commerce, and were based on close links between the intrastate activity and interstate commerce. Unless there was some close connection between the regulation and interstate commerce evincing the need for the federal government to regulate the intrastate activity, the instrumentalities rationale would fail. Thus, in Railroad Retirement Board v. Alton Railroad Co., the Court refused to allow Congress to force intrastate employers to give railway workers certain retirement and pension benefits. ${ }^{115}$ Although the Court recoguized that the pension plan would provide certain social benefits, after examining relevant statistics it concluded that the plan could "have no relation to the promotion of efficiency, economy or safety."116

Thus, the Court's early instrumentalities cases were supported by several different rationales: the use of the instrumentalities of commerce to achieve the specific harm, the protection of the instrumentalities of commerce themselves, and the prevention of economic injury. Importantly, each of these rationales imposed a purpose nexus, ${ }^{117}$ but no other explicit nexus requirements. Consequently, even with a loose purpose nexus, the cases still left open the possibility of congressional regulation based on any harm for which the line crossing was a "but-for" cause.

114. Id. at 351 .

115. 295 U.S. 330, 362-74 (1935).

116. Id. at 367. The Act stated as a purpose the promotion of "efficiency and safety in interstate transportation." Id. at 363. However, the Court concluded the attainment of such purpose could not have been a true feature of the Act, as the statistics demonstrated that the Act would not have any effect on the efficiency and safety of interstate transportation. Id. at 367.

117. By "purpose nexus" 1 mean a requirement that the purpose of the legislation had some nexus to the original purposes behind granting Congress the Commerce Clause power. 


\section{Channels of Interstate Commerce}

The scope of Congress's Commerce Clause power also includes the ability to regulate and protect the "channels of interstate commerce," such as highways, waterways, and airways. This means that, in order to protect the channels of interstate commerce, Congress can regulate persons or goods that pass through interstate commerce. The Court first explicated the rationale underlying the channels prong in Champion v. Ames (the "Lottery Case"), when it upheld a federal law that prohibited the interstatc shipment of lottery tickets. ${ }^{118}$ The Court relied on at least two lines of reasoining in the Lottery Case. First, Justice Harlan reasoned that carrying lottery tickets from one state to another constituted interstate commerce. ${ }^{119}$ Justice Harlan clarified, however, that any carriage across state lines would not suffice; rather, the carriage inust have been performed by an independent carrier, presumably for a fee. ${ }^{120}$ This meant that Justice Harlan's definition of interstate commerce did not extend, for example, to an individual who drove across state lines with a lottery ticket in his pocket. ${ }^{121}$ Next, Justice Harlan discussed the evils associated with lotteries. ${ }^{122}$ Like diseased cattle, which can harm the channels of interstate commerce by spreading disease through those channels to other cattle, Justice Harlan posited that the "evil" tickets could also spread their disease in the channels of interstate commerce. ${ }^{123}$ Thus, the prohibition was necessary to protect the channels of interstate commerce from contamination. ${ }^{124}$

Dissenting, Justice Fuller pointed out the potentially massive implications of sustaining the statute. First, Justice Fuller concluded that the tickets themselves were not commerce. ${ }^{125}$ In addition, he warned that the Court's reasoning left no stopping point. "An invitation to dine, or to take a drive, or a note of introduction, all become articles of commerce under the ruling in this case, by being deposited with an express company for transportation."126

118. Champion v. Ames, 188 U.S. 321, 363 (1903).

119. Id. at 354 ("We are of opinion that lottery tickets are subjects of traffic and therefore are subjects of commerce, and the regulation of the carriage of such tickets from State to State, at least by independent carriers, is a regulation of commerce among the several States.").

120. Id. at 344.

121. Id. at 371 .

122. The Court also discussed the distinction between prohibition and regulation, reasoning that the power to regulate includes the power to prohibit, making the fact that the statute prohibited the activity altogether, rather than merely regulating its use, insiguificant. See id.

123. See id. at 356 ("Experience has shown that the common forms of gambling are comparatively innocuous when placed in contrast with the widespread pestilence of lotteries ... the latter infests the whole community; it enters every dwelling ....") (citing Phalen v. Virginia, 49 U.S. (8 How.) 163, 168 (1850)).

124. See id. at 358.

125. Id. at 369 (Fuller, J., dissenting).

126. Id. at 371 . 
On the one hand, the part of the Lottery Case that focused on the lottery tickets as interstate commerce arguably presented a constricted view of the role of line crossing under the prong. Lottery tickets are subject to sale for value and possess a large economic value to the holder of the winning ticket. Further, the tickets were deposited with an independent carrier (probably at a cost) to be shipped across state lines. Thus, the nexus between the item (a commercial good) and the prohibition (the shipment across state lines) and interstate commerce was, if nothing else, at least tightly connected temporally. ${ }^{127}$

On the other hand, as recognized by Justice Fuller, the Court's reliance on the diseased cattle analogy suggested that the "channels of interstate commerce" rationale bestowed a much broader Commerce Clause power on Congress. Although diseased cattle might actually harm the channels of interstate commerce by transmitting diseases while in transport, the lottery tickets could not spread their "evil" while in transport. Congress may have believed that lotteries theinselves were evil, but the tickets are just paper-hardly comparable to diseased cattle. Using this remarkably weak comparison to diseased cattle, Congress could easily regulate any item or good passing through interstate commerce simply by characterizing it as "evil" and thereby a threat to the channels of interstate commerce, regardless of whether the regulated item or activity could conceivably pose any real threat to other persons or goods im the channels of interstate commerce.

Other cases decided in the same time period reflected dual views of the breadth of the Commerce Clause power. ${ }^{128}$ For instance, in Hoke $v$. United States, the Court sustamed the constitutionality of the White Slave Traffic Act of June 25, which prohibited the transportation in interstate commerce of women and girls for immoral purposes. ${ }^{129}$ As in the Lottery Case, the temporal nexus between the prohibition-the interstate transportation of women and girls for immoral purposes-and the line crossing was tight. Congress was not, for instance, trying to regulate immoral behavior by prohibiting the participation in such behavior when the woman or girl had, at any point in her life, ever crossed state limes. Rather, the defimition of bad behavior included line crossing. In addition, as in the Lottery Case, Congress was prohibiting the use of the channels of interstate commerce to spread "evils."130

127. Of course, the main problem is that Congress was not really trying to protect commerce through its prohibition, but rather trying to exercise a general police power likely not within the purposes behind granting Congress the Commerce Clause power in the first place.

128. E.g., Cleveland v. United States, 329 U.S. 14 (1946); Caminetti v. United States, 242 U.S. 470 (1917); Hoke v. United States, 227 U.S. 308 (1913).

129. Hoke, 227 U.S. at 317-18. See also Caminetti, 242 U.S. 470.

130. Hoke, 227 U.S. at 322-23. 
The Court abandoned any implicit temporal nexus, however, when it considered an application of the Food, Drug, and Cosmetic Act of 1938, which prohibited the alteration, destruction, or removal of a federally mandated label from any food, drug, device, or cosmetic being held for sale after being shipped in interstate commerce. ${ }^{131}$ In United States $v$. Sullivan, Sullivan, a local pharmacist, had purchased pills from out of state, which came shipped in large bottles containing the proper federal warning labels. Before reselling them to in-state customers, Sullivan transferred the pills to smaller bottles without including the federal warning labels required by the act. ${ }^{132}$ The Court upheld the criminal conviction of the pharmacist, based on the fact that the pills had, at one point, traveled through the channels of interstate commerce. ${ }^{133}$

The Court based its decision, in part, upon its earlier holding in McDermott v. Wisconsin, ${ }^{134}$ which considered the Pure Foods and Drug Act of 1906, a variant of the act at issue in Sullivan that had a similar prohibition on misbranding. ${ }^{135}$ In McDermott, the Court found Congress's power to pass the Pure Foods and Drug Act unquestionable:

[Congress] has the right not only to pass laws which shall regulate legitimate commerce among the States and with foreign nations, but has full power to keep the chaunels of such commerce free from the transportation of illicit or harmful articles... and to prevent the facilities of such commerce being used to enable such articles to be transported throughout the country from their place of manufacture to the people who consume and use them .... ${ }^{136}$

The Court in Sullivan thus utilized two rationales for upholding the Food, Drug, and Cosmetic Act: first, the diseased cattle rationale (Congress can protect the channels of interstate commerce from injurious articles) and second, the harm rationale (Congress can prohibit the use of the channels of interstate commerce to conduct specific harms). The dual rationales, however, present dual difficulties. First, the Court took the diseased cattle analogy too far. At least as applied to Sullivan, the articles were not injurious while traveling through interstate commerce. Rather, the "injury" occurred after the articles had passed through the channels, thus presenting no risk to the chaunels of interstate commerce themselves. The Court did not apply a purpose nexus: it expressed no concern that the pharmacist's transfer of the pills to smaller bottles without the federal warning labels posed no actual risks to the channels or instrumentalities of commerce. Second, the Court did not even hint at any sort of temporal

131. United States v. Sullivan, 332 U.S. 689 (1948); 21 U.S.C. $\$ 331(\mathrm{k})(2002)$.

132. Sullivan, 332 U.S. at 691-92.

133. Id. at 697.

134. 228 U.S. 115 (1913).

135. Sullivan, 332 U.S. at 697-98.

136. McDermott, 228 U.S. at 128 (citing Hipolite Egg Co. v. United States, 220 U.S. 45 (1911)). 
nexus requirement. The Court found no problem with the fact that the Food, Drug, and Cosmetic Act only required the articles to have traveled through interstate commerce at some point. Conceivably, the pharmacist's actions could have taken place years after the state-line crossing. While the possibility of a resale of the drugs at issue in Sullivan occurring fifty years after the line crossing might seem remote, given the likelihood that such articles would have some sort of expiration point, when Congress applies the same rationale to articles such as handguns, the limitless nature of the channels prong becomes more evident.

The Court, by failing to define how explicit the nexus between the line crossing and the regulated activity must be, opened the door for more expansive interpretations of what Congress could regulate under the channels and instrumentalities rationales. As the following sections will demonstrate, Congress eventually began to regulate activity based not on a close connection between a line crossing and the regulated activity, but on the fact that a person or good had, at some point, crossed state lines.

\section{The Jurisdictional Element}

The channels and instrumentalities prongs are often referred to in tandem, perhaps refiecting the fact that some cases can be analyzed under either prong. ${ }^{137}$ For instance, Hammer (the child labor case) could be viewed as a case where the Court refused to sustam the legislation because the harm Congress was trying to reach was not created by using the imstrumentalities of commerce. Alternatively, it could be viewed as a case where the Court refused to sustain the legislation because the articles being shipped were not evil in themselves and thus there was no need to protect the channels of interstate commerce from those articles.

Regardless of how they are labeled, channels and instrumentalities cases have presented a muddied view of how close the nexus must be to interstate commerce to sustain legislation. The prior cases utilized different rationales, some of which involved tight links between interstate commerce

137. Some courts also find overlap with the substantial-effects prong. This overlap makes sense with regard to statutes where the jurisdictional element requires a showing that something was "in or affecting commerce" because it is possible for the regulated activity to occur solely intrastate and still affect commerce. In these cases, the substantial-effects prong can be invoked. In other cases, the overlap is due less to the language of the jurisdictional element than simply to the method of the court's reasoning. For instance, in Katzenbach v. McClung, 379 U.S. 294 (1964), the Court sustained the public accommodations provisions of the Civil Rights Act of 1964, holding that Title II prohibited racial discrimination in restaurants. Since Katzenbach involved intrastate activities, the Court analyzed the case under the substantial-effects prong of Congress's Commerce Clause power. Id. at 302 . However, in finding a substantial effect on interstate commerce, the Court relied in part on the fact that the restaurant had purchased some of its food from outside the state. Id. at 304. The Court did not, however, clarify whether its reliance on the line crossing was based on an assumption that the line crossing meant that the restaurant was dealing in goods in interstate commerce, and thus its holding was necessary to protect the channels of interstate commerce, or if its reliance was based on an assumption that the line crossing itself evidenced a substantial effect on interstate commerce. 
(or the channels or instrumentalities of interstate commerce) and the regulated activity, but some of which did not (for instance, those cases utilizing the diseased-cattle rationale). The Court solved much of this confusion/lack of clarity regarding how tight the nexus must be to interstate commerce, however, when it considered the jurisdictional element in United States $v$. Bass ${ }^{138}$ and Scarborough v. United States. ${ }^{139}$

Both Bass and Scarborough involved the felon-in-possession statute which prohibited the receipt, possession, or transportation of a firearm "in commerce or affecting commerce" by a felon. ${ }^{140}$ While Bass only concerned a matter of statutory interpretation, in dicta the Court suggested ways in which the government could satisfy the jurisdictional element. ${ }^{141}$ Significantly, the Court noted that the government could satisfy its burden as to the "receipt" prong of the statute by showing that the firearm had "previously traveled in interstate commerce." 142 The Court in Scarborough, when actually faced with the concrete question of when the jurisdictional element is satisfied, expanded the suggestion it made in Bass to reach the "possession" prong of the statute. ${ }^{143}$ In other words, the Court found that Congress could also satisfy the jurisdictional element and punish mere possession simply by a showing that the firearm had previously traveled in interstate commerce. ${ }^{144}$ Notably, the Court implicitly disavowed any purpose nexus (by noting without pause that the petitioner's theories would "create serious loopholes" in Congress's plan to punish firearm possession by felons), ${ }^{145}$ as well as any temporal or causation nexus ${ }^{146}$ (by noting that Congress intended to broadly reach firearm possessions "with little concern for when the nexus with commerce occurred"). ${ }^{147}$ Though Scarborough involved a matter of statutory interpretation, the Court expressed no reservations about the constitutionality of the statute.

In sum, after Bass and Scarborough, under the channels and instrumentalities prongs of its Commerce Clause power, Congress could regulate any person or good that had ever crossed state lines, even if that line crossing was entirely uncounected with the regulated activity, as long as Congress included a jurisdictional element in the statute. Given that today almost all persons and goods move through interstate commerce at some

138. 404 U.S. $336(1971)$.

139. 431 U.S. 563 (1977).

140. Bass, 404 U.S. at 337; Scarborough, 431 U.S. at 564.

141. Bass, 404 U.S. at 350.

142. Id.

143. Scarborough, 431 U.S. at 577.

144. Id.

145. Petitioners argued that if an individual purchased the gun before his conviction, the fact that the gun had previously traveled in interstate commerce should not satisfy the jurisdictional element. Id. at 576.

146. For discussion of a causation nexus, see infra Part V.A.4.

147. Scarborough, 431 U.S. at 576-77. 
point, the jurisdictional element has devolved into a mere formality. Nevertheless, despite the ease with which Congress could rely on a jurisdictional element to invoke the Commerce Clause power, Congress rarely needed to do so because the Court's expansive view of the substantial-effects prong presented even less of a hurdle. Thus, the implications of permitting Congress to regulate any person, good, or activity with a connection to a state-line crossing went largely unrecognized.

III

LOPEZ AND MORRISON: HOW THE APPARENT "Revolution" IN Congress's Commerce Clause Power Left That Power ESSENTIALLY INTACT

From 1937 until the Court's 1995 Lopez decision, the Court, using a lenient rational-basis standard of review, uniformly upheld congressional statutes against Commerce Clause challenges. ${ }^{148}$ However, the Lopez decision, as surprising as it may have been in light of past Commerce Clause jurisprudence, should not have been a complete surprise. As early as 1976, the Court expressed its concerns about the proper roles of the federal and state governments when it invalidated the application of the Fair Labor Standards Act (FLSA) to state employees in National League of Cities $v$. Usery. ${ }^{149}$ Usery revealed a deeply divided Court. ${ }^{150}$ Although the Court overruled Usery less than ten years later in Garcia v. San Antonio Metropolitan Transit Authority, ${ }^{151}$ in Garcia then-Justice Rehnquist and Justice O'Connor dissented, predicting that the Court would again protect the principles that it briefly protected in Usery. ${ }^{152}$

After a few more personnel changes on the Court, ${ }^{153}$ Chief Justice Rehnquist's and Justice O'Connor's predictions came true. The Gun-Free School Zones Act (GFSZA) criminalized firearm possession within one

148. See supra note 3.

149. 426 U.S. 833 (1976). Though the Court's decision did reflect a concern for placing limits on Congress in order to protect federalism, the Court did not base its holding on Congress's Commerce Clause powers alone. Instead, the decision turned on the fact that the application of the FLSA was to a state entity, and Congress could not impermissibly interfere with "integral [state] government functions." Id. at 851.

150. Justice Blackmun provided the necessary fifth vote, but his concurring opinion expressly limited the application of the holding to the specific facts at issue. See id. at 856 (Blackmun, J., concurring).

151. 469 U.S. 528 (1985). Justice Blackmun switched sides.

152. See id. at 580 (Rehnquist, J., dissenting) (" $[1]$ do not think it incumbent on those of us in dissent to spell out further the fine points of a principle that will, $I$ am confident, in time again command the support of a majority of this Court."); see id. at 580, 589 (O'Connor, J., dissenting) ("The Court today surveys the battle scene of federalism and sounds a retreat. Like Justice Powell, I would prefer to hold the field and, at the very least, render a little aid to the wounded.... I share Justice Rehnquist's belief that this Court will in time again assume its constitutional responsibility.").

153. Justices Kennedy and Thomas, both voting with the majority in Lopez, were appointed to the Court between Garcia and Lopez. 
thousand feet of a school zone. ${ }^{154}$ The district court upheld the provision, and the Court of Appeals for the Fifth Circuit unanimously reversed the district court. ${ }^{155}$ The Supreme Court, in a five-to-four decision, struck down the GFSZA as exceeding the scope of Congress's Commerce Clause power. ${ }^{156}$

Lopez involved a twelfth-grade Edison High School student in San Antonio, Texas who carried a concealed .38 caliber handgun and five bullets to school. ${ }^{157}$ After receiving an anonymous tip, school authorities confronted Lopez, who confessed to the gun possession. ${ }^{158}$ The Texas authorities charged Lopez under Texas law with firearm possession on school premises. ${ }^{159}$ The next day, the Texas authorities dropped the state charges after federal agents charged Lopez with violating the GFSZA. ${ }^{160}$

In the principal opinion, Chief Justice Rehnquist first reviewed the history of the Court's Commerce Clause jurisprudence. He then identified three categories of activity that Congress can regulate. ${ }^{161}$ First, Congress may regulate the use of the channels of interstate commerce. ${ }^{162}$ Second, Congress may regulate and protect the instrumentalities of interstate commerce, or persons or things in interstate commerce, even if the regulated activity is solely intrastate. ${ }^{163}$ Third, Congress may regulate activities that substantially affect interstate commerce. ${ }^{164}$ After determining that possession of a handgun does not fall within the first two categories of Congress's Commerce Clause power, Chief Justice Rehnquist proceeded to analyze the statute under the substantial-effects prong. ${ }^{165}$

Chief Justice Rehnquist identified three grounds for questioning the constitutionality of the GFSZA. ${ }^{166}$ First, the statute had nothing to do with commerce or any sort of economic enterprise. It was just a criminal statute. ${ }^{167}$ Expressing federalism concerns, Chief Justice Rehnquist pointed out that the "[s]tates possess primary authority for defining and enforcing the criminal law." 168 Second, the Chief Justice observed that the GFSZA did not contain a jurisdictional element, "which would ensure, through caseby-case inquiry, that the firearm possession in question affects interstate

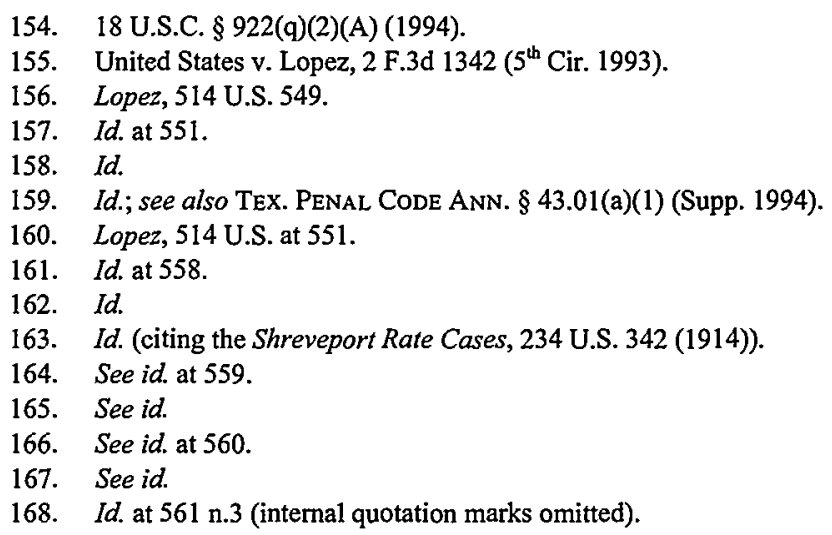


commerce."169 Since the statute in Lopez did not contain a jurisdictional element, the Court did not further discuss this requirement. Consequently, Chief Justice Rehnquist's opinion still could be read to support the argument that a line crossing ensures a connection to interstate commerce, regardless of how distant the line crossing is from the regulated activity. Finally, the Court stated that Congress did not make any formal findings demonstrating that the activity in question substantially affected interstate commerce. ${ }^{170}$ Although findings were not required, Chief Justice Rehnquist suggested that findings would be helpful in close cases like Lopez where it was not obvious how gun possession in a school zone would substantially affect interstate commerce. ${ }^{171}$

Justice Kennedy wrote a separate concurrence, joined by Justice O'Connor, that expressed concerns about maintaining proper federalism boundaries in light of the increasing nationalization of both the economy and society. ${ }^{172}$ Justice Kennedy found that the statute implicated two core elements of federalism. First, since the government's rationale (that possession of a gun in a school zone might result in violent crime, and that violent crime, in turn, has an effect on the national economy $)^{173}$ could be used to demonstrate that any activity has a substantial effect on interstate commerce, it conflicted with the notion that the federal government possesses only limited powers. ${ }^{174}$ Second, Justice Kennedy expressed concern that the federal government might be intruding upon areas that the Constitution reserved for regulation by the states. ${ }^{175}$ "Were the Federal Government to take over the regulation of entire areas of traditional state concern, areas having nothing to do with the regulation of commercial activities, the boundaries between the spheres of federal and state authority would blur and political responsibility would become illusory."176

169. Id. at 561. The Court cited United States v. Bass, 404 U.S. 336 (1971), in support of this proposition. As discussed supra, in Part II.B.3, Bass involved the former 18 U.S.C. \$ 1202(a), which criminalized the reccipt, possession, or transportation of a firearm by a felon "in commerce or affecting commerce." One critical difference between the jurisdictional element discussion in Bass and the proposition Chief Justice Rehnquist cited Bass for in Lopez, however, is that Bass involved a question of statutory interpretation, where the Court found that the nexus requirement modified each component of the statute (receipt, possession, and transportation). The Court in Bass did not, however, discuss the use of a jurisdictional element, in general, to ensure an adequate connection to interstate commerce. In contrast, Chief Justice Rehnquist's citation in Lopez suggests that Bass supports the notion that the inclusion of a jurisdictional element automatically ensures the constitutionality of the statute.

170. Lopez, 514 U.S. at 562-63.

171. See id.

172. See id. at 568-83 (Kennedy, J., concurring).

173. Id. at 563 .

174. See id. at 580 .

175. See id:; see also Choper \& Yoo, supra note 9, at 852.

176. Lopez, 514 U.S. at 577 . Justice Kennedy also pointed out that over forty states had already enacted laws criminalizing the possession of firearms on or near school gronnds, demonstrating that if a state desired to address this problem, it clearly would have the ability to do so. See id. at 581 . 
Justices Breyer, Stevens, Souter, and Ginbsurg dissented. First, they noted that as the Court had understood the commerce power over the last half century, the GFSZA clearly fell within that power. ${ }^{177}$ Second, they criticized the distinction between commercial and non-commercial as being unworkable in today's economy. ${ }^{178}$ Finally, they voiced concern that the ruling created uncertainty in an area of law that, over the last sixty years, had become reasonably settled. ${ }^{179}$

Some commentators thought Lopez signaled a revolution. ${ }^{180}$ Others thought it signaled an evolution. ${ }^{181}$ Some lower courts and commentators doubted altogether whether the Court was serious about enforcing federalism limits on Congress's Commerce Clause power. ${ }^{182}$ As courts and commentators argued over the implications of Lopez and whether the Court's new interpretation of the substantial-effects prong would really protect federalism limits, one major obstacle to protecting those limits went largely ignored. Although the Court limited the substantial-effects prong to cover only commercial activities, it evinced no intention to reexamine the channels or instrumentalities prongs of Congress's Commerce Clause power. In fact, the Court apparently reaffirmed Congress's ability to regulate under those prongs. ${ }^{183}$ Further, by highlighting the absence of a jurisdictional element, the Court implied that its addition would validate an otherwise unconstitutional statute. This implication left open a massive loophole. Very little evidence was required under the Jones and Wickard regime to satisfy the Court that an activity had a substantial effect on commerce. However, even less evidence is required, given today's nationalized markets and society, to show that a car, gun, or person has at some point traveled across state lines.

The Court tried to answer doubts regarding its commitment to the enforcement of federalism boundaries in United States $v$. Morrison, ${ }^{184}$ but still failed to limit the reach of the jurisdictional element. In Morrison, the Court struck down the civil remedy provision of the Violence Against Women Act ("VAWA") ${ }^{185}$ as exceeding Congress's ability to regnlate

177. Id. at 625 (Breyer, J., dissenting) (pointing out that the Court had previously upheld statutes based on far less significant connections to interstate commerce than the connections between school violence and interstate commerce).

178. Id. at 627-30 (Breyer, J., dissenting).

179. Id. at 630-31 (Breyer, J., dissenting). Of course, the dissenting Justices failed to mention that the reasonable settlement point basically allowed Congress to regulate almost any activity.

180. See supra note 2.

181. Choper \& Yoo, supra note 9, at 854.

182. E.g., David B. Sentelle, Lopez Speaks, Is Anyone Listening?, 45 LoY. L. REv. 541, 548-49 (1999).

183. See Lopez, 514 U.S. at 558 ("The authority of Congress to keep the channels of interstate commerce free from immoral and injurious uses has been frequently sustained, and is no longer open to question.").

184. 529 U.S. $598(2000)$.

185. 42 U.S.C. $\$ 13981$ (1994). 
under the Commerce Clause. ${ }^{186}$ Morrison involved an alleged assault and rape at Virginia Polytechnic Institute. Unhappy with the inadequate punishment handed down by the university, Christy Brzonkala, the alleged victim, filed suit against both the alleged attackers and the university under the VAWA. ${ }^{187}$

The Court, inı an opinion written by Chief Justice Rehnquist, first emphasized that "even under our modern, expansive interpretation of the Commerce Clause, Congress's regulatory authority is not without effective bounds." 188 Next, the Court reviewed the reasons behind its Lopez decision, noting the noneconomic, crimmal nature of the conduct, the lack of an express jurisdictional element, and the lack of legislative findings in the GFSZA. ${ }^{189}$ Like the statute at issue in Lopez, the VAWA did not include an express jurisdictional element. ${ }^{190}$ However, unlike the GFSZA, the VAWA contained extensive congressional findings. ${ }^{191}$

The Court seemed even more committed to protecting federalism in Morrison than it did in Lopez. ${ }^{192}$ As in Lopez, the Court began by emphasizing the lack of a jurisdictional element and the noncommercial nature of the provision. ${ }^{193}$ Since the provision was not commercial in nature, the Court rejected Congress's findings that violence against women has a substantial effect on interstate commerce. ${ }^{194} \mathrm{Next}$, the Court reinforced federalism limits by suggesting that there are some substantive areas that might always be beyond federal regulation, regardless of their effect on commerce. 195 "Indeed, we can think of no better example of the police power, which the Founders denied the National Government and reposed in the States, than the suppression of violent crime and vindication of its victims." 196

Thus, although Morrison may have confirmed that Lopez was not an aberration and that the Court intended to rein in Congress's Commerce Clause power for the sake of federalism, these cases' impact on the scope of Congress's porver is in fact quite limited. First, the Court's holdings in both cases were directed to only a narrow subset of the wide range of activities that Congress might seek to regulate: wholly intrastate

186. See 529 U.S. at 601-02.

187. See id. at 602-04.

188. See id. at 608.

189. See id. at 610-11.

190. Id. at 613.

191. See id. at 614.

192. See Choper \& Yoo, supra note 9 , at 853 .

193. 529 U.S. at 613.

194. 529 U.S. at 614-18.

195. Choper \& Yoo, supra note 9, at 853.

196. Morrison, 529 U.S. at 618. 
noneconomic activities that fall under the substantial-effects prong. ${ }^{197} \mathrm{Sec}-$ ond, the Court in Morrison and Lopez did not reexamine the channels or instrumentalities prongs of Congress's Commerce Clause power. Third, the Court impliedly reaffirmed Congress's power to regulate nearly everything as long as Congress included a jurisdictional element in the statute. ${ }^{198}$ Given the history of lenient judicial interpretation of the channels and instrumentalities prongs and the ease with which a jurisdictional element can be incorporated into a statute, it is reasonable to conclude that the Court may have plugged a hole in the dike of federalism but left the floodgates open. In sum, the "revolution" that many hoped (or feared) Lopez and Morrison would bring has done little to limit Congress's still-extensive Commerce Clause power.

\section{IV}

The Jurisdictional Element and Federalism: Why the Commerce Clause Still NeEds Revisiting

The Court's failure to put meaningful limits on the use of a jurisdictional element to invoke Congress's Commerce Clause power leaves federalism in the same place it was before the Court decided Lopez and Morrison-seriously at risk. Federalism depends on limiting the use of the commerce power to when there is a true connection to interstate commerce. The current presumption that the crossing of state lines ensures a connection to interstate commerce is erroneous. The continued growth and increasing integration of the United States economy ensures that almost everything and everyone crosses state lines at some point. But that stateline crossing alone does not ensure a connection to interstate commerce because it takes no account of the circumstances under which it occurred. Thus, a limitation on Congress's commerce power based on a mere line crossing is meaningless and fails to protect federalism.

\section{A. Implications of the Growth of the U.S. Economy}

At the founding period, there was little indication that the United States would experience the rapid economic growth that it did in the late nineteenth century and throughout the twentieth century, growth which was accompanied by an explosion in interstate activity. ${ }^{199}$ The colonies' growth had depended more on producing goods for foreigu markets than for

197. Moreover, the impact of the Court's limitation of the substantial-effects prong to commercial activities is questionable, since the Court did not actually overrule any prior Commerce Clause decisions.

198. See Morrison, 529 U.S. at 618 ("The regulation and punishment of intrastate violence that is not directed at the instrumentalities, channels, or goods involved in interstate commerce has always been the province of the States.").

199. BarRy W. Poulson, Economic History of the United States 53 (1981). 
interstate markets. ${ }^{200}$ However, after 1790 , the American economy began to transition to a period of economic growth that continued throughout the nineteenth century. ${ }^{201}$

Railroad expansion corresponded to, and in large part spurred, the growth of the American economy. ${ }^{202}$ Between 1830 and 1870, the number of miles of railroad track in operation increased by 229,996 percent. ${ }^{203} \mathrm{Be}$ tween 1870 and 1890 , the number of miles of operable track increased by another 214 percent, ${ }^{204}$ and between 1890 and 1931, the number of miles of operable track increased by 157 percent. ${ }^{205}$ While these numbers do not precisely reflect the increase in the number of people and goods crossing state lines, they do demonstrate that the potential, and thus the likelihood, of state line crossings increased incalculably. The mcreasing revenues collected from railroad freight also evince a correspondence between the expansion of railway track and the increasing shipment of goods interstate. In 1890 , railway freight revenue was an estimated $\$ 714,464.00$. In 1957 , that number had grown substantially, to over $\$ 9$ million. ${ }^{206}$

When railroad growth slowed, travel by motor vehicles increased. Between 1921 and 1996, the number of miles of roads and streets increased by 35 percent. ${ }^{207}$ This growth in infrastructure corresponds to the enormous growth in the number of miles traveled by motor vehicles. In 1921, motor vehicle owners in the United States drove an estimated 55,027 million miles. ${ }^{208}$ In 1957, motor vehicle owners drove an estimated 647,004 million miles. ${ }^{209}$ Furthermore, recent figures suggest that the amount of interstate travel is still increasing. In 1985, the United States Census Department estimated that Americans took about 156.6 million trips more than 100 miles from home. ${ }^{210}$ In 1994, Americans took 434.3 million trips more than 100 miles from home. ${ }^{211}$

200. Id. at 69 .

201. Id. at 217. Though the growth slowed at times during the twentieth century, most notably during the Great Depression, the United States generally has maintamed its growth trend. Id. at 443-44.

202. For the view that the economic history of the Umited States in the second half of the nineteenth century was dominated by the railroad sector, see JOSEPH A. SCHUMPETER, THE THEORY OF ECONOMIC DEVELOPMENT (1934).

203. See Historical Statistics, supra note 74 , at 427.

204. Id.

205. See DR. Yardeni's Economics Network: Economic History: LAND, LABor \& CAPITAL, at http://www.yardeni.com/public/hislan_c.pdf (June 25, 2001) [hereinafter LAND, LABOR \& CAPITAL].

206. See Historical Statistics, supra note 74, at 431 .

207. See LAND, LABOR \& CAPITAL, supra note 205.

208. Historical STATISTICS, supra note 74, at 463.

209. Id.

210. United States Department of Commerce \& Bureau of the Census, Statistical ABSTRACT OF THE UNITED STATES: 1996 (1997), available at http:/www.census.gov/prod/2/ 96statab/parks.pdf (last visited July 17, 2001) [hereinafter STATISTICAL ABSTRACT 1996]. This figure includes some intrastate travel, but the increase demonstrates an increase in both intrastate and interstate travel.

211. Id. 
Not only have transportation networks expanded, but communications networks have also grown. In 1912 the United States Census Department estimated that there were approximately 20,248 thousand miles of telephone wire in the United States. In 1990, that estimate grew to 1,528 million miles, a 655 percent increase. ${ }^{212}$ Even in recent years, the number of households with telephone service has grown substantially. In 1970, 87 percent of households had telephone service, whereas by 1998, 94.1 percent of households had the service. ${ }^{213}$

These numbers are significant in that they show that more persons and goods than ever are crossing state lines. They further indicate that almost every activity or transaction is connected, however remotely, to something or someone that has crossed state lines. Thus, the federal government, if it can rely on a mere state-line crossing as justification for exercising Commerce Clause power, is potentially empowered to regulate almost all intrastate activities. For example, it could regulate all of our textbooks in public schools or assigu FBI agents to hand out parking tickets on local streets. After all, the paper those books and tickets are printed on probably traveled across state lines at some point. And, since streets can be considered channels of commerce, and automobiles can be considered instrumentalities of commerce, everything counected to streets or automobiles could be considered appropriate subjects for regulation. Even before the Court decided Lopez and Morrison, Judge Wiseman pointed out the limitlessness of these notions:

If anything that will take you across a state line is an "instrumentality of commerce," then there is justification for Congress to regulate anything done on a bicycle or, for that matter, on foot. The Framers traveled to Philadelphia on horseback or by horse and carriage. Can it be imagined that in constructing the Commerce Clause they intended to regulate and punish horse stealing? $?^{214}$

The Court's failure to limit the jurisdictional element means Congress can continue to use it to reach almost anything it deems a social problem. Professors Choper and Yoo have suggested that Congress might be able to regulate divorce by providing that any person who either has ever traveled or who plans to travel in the future using the channels or instrumentalities of interstate commerce must meet federal standards in order to obtain a

212. United States Department of Commerce \& Bureau of the Census, Statistical ABstract of THE United STATES: 1942 (1943) [hereinafter Statistical ABSTRACT 1942]; see also United States Department of Commerce \& Bureau of the Census, Statistical abstract of THE UNITEd STATES: 1995 (1996) [hereinafter StatistiCal AbSTRACT 1995].

213. United States Department of Commerce \& Bureau of the Census, Statistical ABSTRACT OF THE UNITED STATES: 2000, at http://www.census.gov/prod/2001 pubs/statab/sec18.pdf (last visited Aug. 1, 2001).

214. United States v. Cortner, 834 F. Supp. 242, 243 (M.D. Tenn. 1993). 
divorce. ${ }^{215}$ Choper and Yoo have also suggested that Congress could regulate same-sex marriages, either by refusing to allow anyone married under a state same-sex marriage law to cross state boundaries, or by refusing to allow someone to enter into a same-sex marriage if they have ever traveled across state lines. ${ }^{216}$ These examples demonstrate that a jurisdictional eleinent without some nexus requirement connecting the line crossing and the regulated activity would allow Congress to reach just about anything, even areas historically left to the states such as family law.

Of course, most of this seems inconceivable to us at this point. However, the reality of the threat to federalism posed by an unrestricted jurisdictional element is illustrated by the revised GFSZA. ${ }^{217}$ Taking the Court's cue that it would not review the channels and instrumentalities prongs of Congress's Commerce Clause power, Congress passed a revised version of the GFSZA, adding that the firearm in question must have "moved in" or must "otherwise affect[] interstate or foreign commerce."218

Although the Court stated in Lopez that Congress cannot have a general police power, ${ }^{219}$ and although the rationales espoused in the early channels and instrumentalities cases were probably never intended to justify congressional regulation of a firearm that had once passed through interstate commerce via a state lime crossing fifty years earlier, the revised GFSZA shows that Congress is likely to use the jurisdictional element to accomplish regulation with only an attenuated link to interstate commerce. If the Court wants to protect federalism, it must revisit the jurisdictional element because a state-line crossing, in itself, simply does not create a real connection to interstate commerce anymore.

The Court probably did not intend Lopez to serve as a mere statutedrafting seminar. Given the federalism principles underlying Lopez and Morrison, it seems absurd to suggest that all it takes to avoid undermining those principles is to prove that a firearm was shipped in interstate commerce at some point in its existence. However, by emphasizing the lack of a jurisdictional element in Lopez, the Court implied that such an element would ensure that the gun in question would indeed affect imterstate commerce if it had crossed state lines. Consistent with this observation, the lower federal courts have consistently upheld statutes based on the mere presence of a jurisdictional elennent.

215. See Choper \& Yoo, supra note 9, at 862-63.

216. See id. at 863 .

217. 18 U.S.C. $\$ 922$ (q) (1994 \& Supp. 1 1996).

218. See id. at $\S 922(\mathrm{q})(2)(\mathrm{a})$.

219. Lopez, 514 U.S. at 566. 


\section{B. Lower Court Decisions}

If the Court did not intend Lopez and Morrison to serve as mere drafting lessons, then adherence to the Lopez and Morrison principles requires courts to place some limitation on the jurisdictional element by requiring a closer nexus between the line crossing and the regulated activity. A brief look at how lower federal courts have handled challenges to other federal statutes since Lopez and Morrison supports this point. While Lopez and Morrison may have given hope to many criminal defendants by providing another rationale with which to challenge their convictions, the lower courts have, for the most part, summarily rejected such challenges.

\section{Federal Carjacking Statute}

The federal carjacking statute is rooted in the Dyer Act, enacted in 1919, which prohibits both the transportation of stolen motor vehicles in interstate commerce and the receiving, concealing, or disposing of stolen vehicles that have been transported across state lines. ${ }^{220}$ Congress enacted the Dyer Act in response to interstate auto thefts where stolen vehicles would be taken across state lines in order to dispose of the vehicles or the parts, and it proved to be an effective tool in combating such thefts. ${ }^{221}$

More than seventy years later, Congress enacted the federal carjacking statute, which makes it a federal crime to "take[] a motor vehicle that has been transported, shipped, or received in interstate or foreign commerce from the person or presence of another with the intent to cause death or serious bodily harm." 222 Although the acts regulated by the two statutes are similar in that they both involve stolen vehicles, their respective connections to interstate commerce are dramatically different. While the Dyer Act was aimed at preventing the interstate transportation of stolen motor vehicles or parts, the federal carjacking statute is aimed at preventing carjacking. In the latter case, the only connection to interstate commerce is often that the car was shipped across state lines from the manufacturer to the dealership. ${ }^{223}$ In contrast, in the Dyer Act, the line-crossing element is intimately connected to the regulated activity because it is the line crossing that has created the special harm. The statute is intended to reach the specific subset of perpetrators who not only steal cars, but who also take the cars across state lines, possibly to sell them. It is the line crossing itself that makes the criminals harder to prosecute by state officials and therefore justifies federal action. In contrast, the purpose of the federal carjacking

220. 18 U.S.C. $\S \S 2311-2313$ (2002).

221. See 58 Cong. REc. H5470, H5471 (1919) (statement of Rep. Dyer); see also Kathleen F. Brickey, The Commerce Clause and Federalized Crime: A Tale of Two Thieves, 543 Annals Am. ACAD. Pol. \& Soc. ScI. 27, 29-30 (1996).

222. 18 U.S.C. $\$ 2119(2002)$.

223. E.g., United States v. Johnson, 22 F.3d 106, 108 (6th Cir. 1994). 
statute is to reach any carjacker, regardless of whether the perpetrator takes the carjacked vehicle across state lines.

The jurisdictional element in the carjacking statute does little more than create a slightly higher burden on the prosecution. In each prosecution, the prosecutor must not only prove the act of carjacking but also that the vehicle has crossed state lines. Like guns, virtually all motor vehicles move in interstate commerce at some point, often before they are even sold. Thus, satisfying the element is generally little more than a formality, albeit a formality that has supported the lower courts' almost unanimous decision to sustain the constitutionality of the statute against Lopez and Morrison challenges. ${ }^{224}$

Finally, the absurd results that ensue in the rare cases where the prosecutor cannot prove the line crossing demonstrate the inadequacy of relying on an unrestricted jurisdictional element to justify the use of Congress's Commerce Clause power. ${ }^{225}$ In those cases, the criminal defendant, though his alleged crime mirrors that of other defendants prosecuted under the statute, is acquitted on federal charges because there was no line crossing, despite the fact that the car stolen likely has the same connection to interstate commerce as another car that a prosecutor could prove was shipped in interstate commerce years ago. For example, in United States $v$. Gamble, a case involving an alleged carjacking in Michigan, the government introduced figures that showed that more than 25 percent of all passenger cars and trucks made in America are made in Michigan, and over 50 percent of all vehicles made in America are made im either Michigan, Ohio,

224. See, e.g., United States v. Cobb, 144 F.3d 319, 320-22 (4th Cir. 1998); United States v. McHenry, 97 F.3d 125, 126-29 (6th Cir. 1996), cert. denied, 519 U.S. 1131 (1997); United States v. Coleman, 78 F.3d 154, 157-60 (5th Cir. 1996), cert. denied, 519 U.S. 891 (1996); United States v. Bishop, 66 F.3d 569, 575-90 (3d Cir. 1995), cert. denied, 516 U.S. 1032 (1995); United States v. Robinson, 62 F.3d 234, 235-37 (8th Cir. 1995). The courts in most of these cases have, at least in part, relied on the presence of a jurisdictional element in the carjacking statute to reject Lopez-based attacks. See Cobb, 144 F.3d at 321-22; Coleman, 78 F.3d at 159; Bishop, 66 F.3d at 585-88; Robinson, 62 F.3d at 236-37; United States v. Taylor, 226 F.3d 593, 600 (7th Cir. 2000) ("Repeatedly since Lopez we have held that a jurisdictional element ensures sufficient nexus with interstate commerce to withstand Commerce Clause challenges.") (citing Gillespie v. City of Indianapolis, 185 F.3d 693, 704-05 (7th Cir. 1999); United States v. Wilson, 159 F.3d 280, 285-87 (7th Cir. 1998)). Despite the fact that many carjackings likely involve completely intrastate activity, such as those that occur in the driveways of private residences, some lower courts have avoided the potential implications of Lopez and Morrison altogether by analyzing the carjacking statute as a statute that is designed to regulate and protect the channels of interstate commerce. See, e.g., McHenry, 97 F.3d at 126-29 (sustaining the statute under both the instrumentalities prong and the substantial-effects prong of Congress's Commerce Clause power by finding that the carjacking statute regulates economic activity); see also Cobb, 144 F.3d at 322 (finding the carjacking statute constitutional and the required analysis unchanged by Lopez because the statute, in the court's opinion, regulated the instrumentalities of commerce). Some courts have based their holdings on the notion that cars are instrumentalities of interstate commerce. See, e.g., Cobb, 144 F.3d at 322; United States v. Oliver, 60 F.3d 547, 550 (9th Cir. 1995); United States v. Watson, 815 F. Supp. 827, 831 (E.D. Pa. 1993).

225. E.g., United States v. Gamble, 939 F. Supp. 569 (E.D. Mich. 1996). 
or Kentucky. ${ }^{226}$ The jury acquitted the defendant because the prosecution could not prove the car had ever left Michigan. ${ }^{227}$ The figures suggest that residents of Michigan, Ohio, and Kentucky are protected less by the federal carjacking statute than other states because the federal statute links protection to a state-line crossing. An absurd corollary to this observation is that carjacking in Michigan is much less connected to interstate commerce than carjacking in Idaho. The lesson, then, seems to be that if you want to be a carjacker, you should pack up your bags and move to Michigan or Ohio, where a line crossing is hard to prove, and steal a new rather than an old car, thereby making the line crossing even harder to prove. ${ }^{228}$

\section{Felon-in-Possession Statute}

Federal statutes govern the licensing, sale, transportation, possession, and use of firearms. ${ }^{229}$ Like many other criminal statutes, the firearms statutes have also come nnder Lopez- and Morrison-based attacks, though most of those attacks have failed. ${ }^{230}$ The felon-in-possession statute, which contains a jurisdictional element, provides a clear example of the failings I have pointed out in Lopez and Morrison. The statute criminalizes a felon's possession of a firearm that is "in or affecting commerce" and forbids a felon from receiving or transporting any firearms which have been "shipped or transported" in interstate or foreigu commerce. ${ }^{231}$ The jurisdictional requirement in the felon-in-possession statute requires only a showing that the gun has crossed a state line at soine point since its manufacture. ${ }^{232}$ The government need not show any close temporal connection between the line crossing and the felon's possession of the firearm to satisfy the jurisdictional element. Though the Supreme Court interpreted the reach of the felon-in-possession statute before it decided Lopez and Morrison, ${ }^{233}$ the lower courts' post-Lopez and Morrison interpretations of the statute have not changed. For instance, in United States v. Gallimore, the Fourth Circuit noted that "the Government may establish the requisite interstate commerce nexus by showing that a firearm was manufactured

226. Id. at 571 n.1.

227. Id. at 570-71.

228. Carjackers should also probably learn to avoid states like Iowa, where no automobiles are manufactured. See id.; see also United States v. Cortner, 834 F. Supp. 242, 243 (M.D. Tenn. 1993). The Cortner court pointed out that, at that time, all Saturn automobiles were made in Tennessee. Id. at 243 . If the public welfare truly required the legislation, Congress unfairly discriminated against Saturn owners in Tennessee, who would not be covered by the statute. Id.

229. E.g., 18 U.S.C. $\$ \$ 921-930$ (1994).

230. See infra notes 224-27.

231. 18 U.S.C. $\$ 922(\mathrm{~g})(2000)$. For another example of a firearms statute that contains a specific jurisdictional element, see 18 U.S.C. $\$ 922(q)(2)(A)(2002)$ (the amended GFSZA).

232. Scarborough v. United States, 431 U.S. 563,577 (1977).

233. See id. 
outside the state where defendant possessed it."234 The Sixth Circuit has similarly noted that Lopez did not change the analysis under the felon-inpossession statute. ${ }^{235}$

The Tenth Circuit took a different approach to avoiding the constraints of Lopez. It viewed the jurisdictional element as solely implicating the channels prong, even though the language of the statute ("in or affecting commerce") means that the statute might cover solely intrastate activity that affects commerce. ${ }^{236}$ But the Tenth Circuit's approach to the felon-in-possession statute illustrates the weakness of a channels rationale based on a remote line crossing. If Congress's purpose was to keep the channels of interstate commerce free from all firearms, then the felon-inpossession statute was a terrible way to do it, as it only covers firearms possessed by felons, hardly the majority of firearms in the United States. Of course, Congress can fight one evil at a time; but to claim that Congress enacted this legislation to protect the channels of interstate commerce seems highly suspect in light of the extremely limited ability of this statute to serve that purpose. Further, if Congress had a narrower purpose, such as to protect the channels of interstate commerce from firearms possessed by felons, then it would have made more sense to focus on the interstate

234. 247 F.3d 134, 138 (4th Cir. 2001).

235. United States v. Napier, 233 F.3d 394, 400 (6th Cir. 2000) ("'Lopez . . . did not disturb the Supreme Court's precedents which indicate that a firearm that has been transported at any time in interstate commerce has a sufficient effect on commerce to allow Congress to regulate the possession of the firearm pursuant to its Commerce Clause powers."') (quoting United States v. Chesney, 86 F.3d 564, 571-72 (6th Cir. 1996)) (emphasis original in Napier).

236. United States v. Dorris, 236 F.3d 582 (10th Cir. 2000), cert. denied, 532 U.S. 586 (2001). The court noted:

Section $922(\mathrm{~g})(1)$ by its language only regulates those weapons affecting interstate commerce by being the subject of interstate trade. It addresses items sent in interstate commerce, and the channels of interstate commerce themselves-ordering they be kept free of firearms. Thus, no analysis of the style of Lopez or Morrison is appropriate.

Id. at 584. One court, when considering a statute that did not contain an explicit jurisdictional element, read one in to avoid Lopez and Morrison. United States v. Kirk, 70 F.3d 791 (5th Cir. 1995), aff'd en banc, No. 94-50472, 1997 U.S. App. LEXIS 12670 (1997) (considering the machine gun statute, which prohibits the transfer or possession of a machine gun after May 19, 1986). The majority relied on the inference that because the statute prohibits transfer as well as possession, the channels of interstate commerce are implicated. Id. at 796-97. Judge Jones, dissenting from the Kirk court's decision to sustain the statute under the channels prong, pointed out the problems with the majority's reasoning. Judge Jones aptly noted that both transfer and possession can occur wholly intrastate, and that "mere intrastate possession of a machine gun is not a use of the channels of interstate commerce any more than mere intrastate possession of a basketball." Id. at 799-80 (Jones, J., dissenting). See also United States v. Beuckelaere, 91 F.3d 781 (6th Cir. 1996). Dissenting in Beuckelaere, Judge Suhrheinrich wrote:

Instead of adhering to the framework suggested by Lopez, however, the majority strains the limits of the first two categories [channels and instrumentalities] to buttress its decision. Attempting to bring $\$ 922(0)$ [the machine gun statute] within the first Lopez category [channels], it indicates that prosecution under $\$ 922(0)$ necessarily involves an illegal transfer implicating the channels of imterstate commerce. This view overiooks the plain language of the statute, which clearly allows prosecution for mere possession of a machine gun.

Id. at 788. (Suhrheinrich, J., dissenting). 
movement of the gun after the felon gained possession of it, rather than before. The most rational explanation, however, is that Congress's purpose in enacting the statute had nothing to do with the channels of interstate commerce at all. Rather, the effect of the statute indicates that Congress's purpose in enacting it was to prohibit the possession of firearms by felons, regardless of any connection to interstate commerce or its channels and instrumentalities. While it seems clear that the lower federal courts are generally reluctant to enforce the federalism boundaries underlying Lopez and Morrison, it must also be noted that the Supreme Court, by declining to overrule Scarborough, enabled the lower courts to pursue this course. Thus, lower courts intcrpreting the felon-in-possession statute can rely on precedent from the Supreme Court that says that a line crossing at any point in time satisfies the statute's jurisdictional element. ${ }^{237}$

Statutes regulating motor vehicles and firearms are two of the most obvious examples of the problem created by using a jurisdictional element without any additional nexus requirement. Both guns and automobiles are primarily manufactured in certain areas; thus it is unusual to find a gun or automobile that has not, in its lifetime, crossed a state line. As a result, Congress has the ability, based solely on a state-line crossing, to regulate nearly all firearms and automobiles. The willinguess of Congress to exploit this tenuous but powerful connection to the Commerce Clause power is illustrated by a bill proposed in 1991 and again in 1993, where Congress sought to make it a federal crime to commit any state crime with a firearm that had crossed state lines. ${ }^{238}$

The problem is not, however, limited to the regulation of specific goods that are manufactured in only a few areas and thus almost always cross state lines. Since the Supreme Court has not placed any real limitations on the usc of the jurisdictional elemcnt to sustain facial constitutionality, Congress could conccivably regulate any person, good, or activity as long as the person or good, or a person or good connected to the activity, has crossed a state line.

\section{Federal Arson Statute}

The federal arson statute criminalizes the malicious damage or destruction by fire or explosive of "any building, vehicle, or other real or personal property used in interstate or foreign commerce or in any activity

237. See United States v. Bowens, 108 F. Supp. 2d 1067, 1072 (N.D. Cal. 2000). The court noted:

[T] he Lopez trilogy only even arguably overrules the constitutional premise allegedly implicit in Scarborough's 'minimal nexus' construction of $\S 922(\mathrm{~g})$ 's prececessor [felon-inpossession] if the activity regulated in $\S 922(\mathrm{~g})$ is category three $\ldots . \S 922(\mathrm{~g})$ regulates category two activity. Under this approach, the constitutionality of $\S 922(\mathrm{~g})$ 's possession prong ... remains undisturbed by the Lopez trilogy.

Id. at 1072-73.

238. Violent Crime Control Act of 1991, S. 1241, 102d Cong. (1991); Violent Crime Control and Law Enforcement Act of 1994, H.R. 3355, 103d Cong. (1994). 
affecting [such] commerce."239 In Jones $v$. United States, a unanimous Court held that a private home that received natural gas from out of state did not satisfy the jurisdictional requirement of the arson statute. ${ }^{240}$ The Court's analysis focused on the term "use" as Justice Ginsburg, writing for the Court, emphasized that the property was used as a home, "the center of ...family life," not in "any trade or business."241 The Court's limiting interpretation of the statute is due to the language requiring "use" in commerce. However, the Court also relied on the maxim that if a statute is susceptible of two interpretations, one of which would raise serious constitutional concerns, it must adopt the other. ${ }^{242}$ The Court recognized that adopting the government's argument that the home was "used" in interstate commerce because it received natural gas from out of state would mean that "hardly a building in the land would fall outside the federal statute's domain."243 Even the four Lopez dissenters, including Justice Ginsburg, recoguized that a broad reading of the federal arson statute might, even under an expansive definition of Congress's Commerce Clause power, raise constitutional problems. ${ }^{244}$ Thus, the Jones opimion indicated that there are some minimal connections to interstate commerce that will not satisfy the jurisdictional eleinent. However, those limitations are themselves limited. The Court considered arson to be an unquestionably local crime. ${ }^{245}$ It is unclear whether the Court would express the same concerns if the conduct in question were not deemed to be as unquestionably local.

Consistent with a straightforward interpretation of the statute's language, most of the cases arising from the federal arson statute involve buildings with tenants engaged in commercial activities or buildings being rented or leased. ${ }^{246}$ Lower court cases suggest that the statute's reach is growing, however. In United States v. Milton, the Kansas District Court sustained the statute's application to a church based on the fact that cliurches receive many of their supplies from out of state and often transfer funds across state lines. ${ }^{247}$ Further, the Eleventh Circuit has suggested that if a private home contains the resident's home office, and the computer in

239. 18 U.S.C. $\$ 844$ (i) (1994).

240. 529 U.S. $848,855-59$ (2000).

241. Id. at 856.

242. Id. at 857.

243. Id.

244. Id. at 858 .

245. Id.

246. See, e.g., United States v. Tocco, 135 F.3d 116 (2d Cir. 1998) (building containing clothing stores and apartments), cert. denied, 523 U.S. 1096 (1998); United States v. Utter, 97 F.3d 509 (11th Cir. 1996), cert. denied, 531 U.S. 858 (2000) (restaurant); United States v. DiSanto, 86 F.3d 1238 (1st Cir. 1996), cert. denied, 520 U.S. 1105 (1997) (rented restaurant).

247. 966 F. Supp. 1038, 1041 (D. Kan. 1997). 
that home office is equipped with a modem linking it to interstate phone lines, the jurisdictional element would be satisfied. ${ }^{248}$

Lower courts faced with Lopez and Morrison challenges to the federal arson statute usually engage in very little Commerce Clause analysis due to the presence of the jurisdictional element. Instead, they assume that if the jurisdictional element is satisfied, the statute is constitutional, even if the decision completely undermines the federalism principles in Lopez and Morrison. ${ }^{249}$ Although the Court's opinion in Jones signaled that statutory language like "used in interstate or foreigu commerce" can serve a limiting function, it did not foreclose the lower courts from relying on remote connections with interstate commerce to satisfy that language.

\section{Child Support Recovery Act}

As mentioned earlier, without limitations on the use of the jurisdictional element to establish constitutionality, Congress could conceivably regulate areas traditionally left for the states, such as family law. For instance, the Child Support Recovery Act (CSRA) illustrates Congress's use of the Commerce Clause power to justify a foray into domestic relations. The CSRA criminalizes the willful failure to pay past-due child support for a child that lives in a different state. ${ }^{250}$ Congress enacted the CSRA to combat the difficulties faced by some states when they attempt to gain jurisdiction over a nonresident defendant who has failed to pay child support; often the custodial parent was forced to sue in a foreign jurisdiction. ${ }^{251}$ However, the jurisdictional element in the statute requires only that the defendant must reside in a different state than the child. ${ }^{252}$ Thus, the statute requires no connection between the line crossing and the willful failure to pay by the defendant. A defendant can be found guilty under the act even when it was the custodial parent who moved out of state, rather than the defendant.

As with the other statutes containing jurisdictional elennents, however, the lower courts cannot agree on which prong of Congress's Commerce Clause power applies to the CSRA. For instance, the Seventh Circuit sustained the CSRA because it deemed it to be a regulation of a "thing' in interstate commerce."253 The Third Circuit, on the other hand, upheld the

248. See United States v. Denalli, 73 F.3d 328, 330-31 (11 th Cir. 1996).

249. See Nelson \& Pushaw, supra note 55, at 153.

250. 18 U.S.C. $\$ 228$ (a) (1994).

251. See Ronald S. Kornreich, Note, The Constitutionality of Punishing Deadbeat Parents: The Child Support Recovery Act of 1992 After United States v. Lopez, 64 FordHAM L. Rev. 1089, 1093 (1995).

252. 18 U.S.C. $\& 228(a)(1)$ (1994). The statute only refers to "a child who resides in another State." It does not have any requirements regarding how the parent and child came to reside in different states.

253. United States v. Black, 125 F.3d 454, 460 (7th Cir. 1997), cert. denied, 523 U.S. 1033 (1998); see also United States v. Bailey, 115 F.3d 1222, 1229-30 (5th Cir. 1997), cert. denied, 522 U.S. 
CSRA based on the substantial-effects prong, relying primarily on extensive findings showing the effect of delinquent child support obligations on interstate commerce. ${ }^{254}$ Finally, a Virginia district court upheld the statute based solely on the presence of the jurisdictional element requiring that the defendant must reside in a different state than the child. ${ }^{255}$

Not all lower courts have upheld the CSRA. In United States $v$. Schroeder, the district court struck down the CSRA as unconstitutional after finding that it failed under the substantial-effects prong. ${ }^{256}$ The court reasoned that the jurisdictional element requiring the noncustodial parent and child to live in different states did not establish enough of a link to interstate commerce to support congressional regulation. ${ }^{257}$ However, the Ninth Circuit reversed, finding the CSRA to be constitutional under the channels and instrumentalities prongs. ${ }^{258}$

Schroeder raises an important point. Some statutes will fall under more than one prong of Congress's Commerce Clause power. However, none of them should fall under both the substantial-effects prong and either of the channels or instrumentalities prongs because the substantial-effects prong is intended to analyze wholly intrastate activities. Courts' confusion on this point ${ }^{259}$ demonstrates the difficulty of distinguishing interstate subjects from intrastate subjects when the state-line crossing is remote. ${ }^{260}$

\section{Other Statutes}

While I have discussed some of the areas that have faced the most frequent Lopez- and Morrison-based challenges, the lower courts have also heard Lopez- and Morrison-based attacks on the Racketeer Influenced and Corrupt Organizations Act, ${ }^{261}$ the Hobbs Act, ${ }^{262}$ the Endangered Species

1082 (1998); United States v. Mussari, 95 F.3d 787 (9th Cir. 1996), cert. denied. 1997 U.S. LexIs 2776; United States v. Bongiomo, 106 F.3d 1027, 1031-32 (1st Cir. 1997) (finding child support orders to be "functionally equivalent to interstate contracts" and thus "'things' in interstate commerce").

254. See United States v. Parker, 108 F.3d 28, 30 (3d Cir. 1997), cert. denied, 522 U.S. 837 (1997).

255. See United States v. Murphy, 893 F. Supp. 614 (W.D. Va. 1995).

256. 894 F. Supp. 360 (D. Ariz. 1995), rev'd, 95 F.3d 787 (9th Cir. 1996).

257. Id. at 364-65.

258. Mussari, 95 F.3d at 790-91.

259. In addition to the aforementioned courts presenting conflicting views of which prong of the Commerce Clause power applies, some courts have simultaneously applied all three prongs. See United States v. Williams, 121 F.3d 615, 619 (1 th Cir. 1997), cert. denied, 523 U.S. 1065 (1998) (upholding that statute under all three prongs, channels, instrumentalities, and substantial effects); United States v. Crawford, 115 F.3d 1397, 1400 (8th Cir. 1997), cert. denied, 522 U.S. 934 (1997) (same).

260. Some of this confusion likely results from the Court's reference to the lack of a jurisdictional element in Lopez, a substantial-effects case. Still, courts are generally more prone to thinking about the jurisdictional element in the context of the channels and instrumentalities prongs.

261. See, e.g., United States v. Jackson, No. 96-CR-815, 2000 U.S. Dist. LEXIS 17221 (N.D. 111. 2000) (upholding the convictions based on a finding that the defendant's activity had an effect on interstate commerce); United States v. Kee, No. S1-98-CR-778, 2000 U.S. Dist. LEXIS 8784 (S.D.N.Y. 2000 ) (relying on the presence of a jurisdictional element to reject a facial challenge to RICO). 
Act, ${ }^{263}$ and the federal obscenity statute. ${ }^{264}$ Whether these lower court decisions are based upon an explicit or implied jurisdictional nexus requirement, the results have been as inadequate in protecting federalism as those discussed under the carjacking, firearms, and CSRA statutes. Furthermore, as with the cases previously discussed, many of these lower court decisions illustrate that a line crossing simply does not ensure a sufficient connection to interstate commerce anymore.

For example, in United States $v$. Schaffner, Schaffner appealed from a conviction of sexual exploitation of a child. ${ }^{265}$ The federal statute at issue allowed the prosecutors to charge Schaffner with the persuasion, inducement, enticement, or coercion of a minor to engage in any sexually explicit conduct for the purpose of producing visual depictions of the conduct, so long as the visual depiction has been transported or mailed in interstate commerce. ${ }^{266}$ The purpose of the statute was to thwart the interstate trade in child pornography. ${ }^{267}$ Schaffner drove a 15 -year-old girl across state lines, and took nude photographs of her while staying at different motels. ${ }^{268}$ Schaffner eventually drove the girl back home, again across state lines. ${ }^{269}$ One month later, someone discovered one of the nude photographs hidden inside Schaffner's bathroom, and Schaffner was prosecuted under section 2251(a). ${ }^{270}$ Based on the evidence that Schaffner carried the photograph across state lines while returning home, the court sustained the conviction. ${ }^{271}$

While there was a close time nexus between the interstate carriage of the photograph and the act in question, and few would doubt that Schaffner's conduct should be criminalized, the case still presents problems. If Congress's authority is to regulate interstate commerce, it is difficult to see how Schaffner's act of carrying the photograph across state lines and then stashing it in his bathroom had anything to do with interstate commerce. The purpose of the jurisdictional element is to ensure, on a case-by-case basis, that the act in question has a connection to interstate

262. See, e.g., United States v. Peterson, 236 F.3d 848, 852 (7th Cir. 2001) (holding that even after Morrison, only a showing of a de minimus effect is required to satisfy the jurisdictional element); United States v. Wang, 222 F.3d 234 (6th Cir. 2000) (reversing the defendant's conviction, reasoning that after Lopez and Morrison, a stronger connection to interstate commerce is required).

263. E.g., Gibbs v. Babbitt, 214 F.3d 483 (4th Cir. 2000) (rejecting a Commerce Clause challenge to a regulation limiting the taking of red wolves on private land).

264. See, e.g., United States v. Schaffner, 258 F.3d 675 (7th Cir. 2001) (holding that the defendant's transportation of an obscene photo across state lines provided a sufficient nexus to commerce to justify regulation).

265. Id. at 676 .

266. 18 U.S.C. $\$ 2251$ (a) (1994).

267. Schaffner, 258 F.3d at 680.

268. - Id. at 675 .

269. Id. at 677 .

270. Id.

271. Id. at 675 . 
commerce. ${ }^{272}$ Although Congress may have other adequate justifications to regulate Schaffner's actions, those justifications hardly stem from the stateline crossing.

Finally, the growth of communications networks across the United States has greatly increased the likelihood that any activity will involve some line crossing and thus potentially permits all activities to be regulated under the Court's current approach to the jurisdictional element. Indeed, one Tenth Circuit case has held that internet communications can establish a line crossing sufficient to invoke Congress's Commerce Clause power. In United States $v$. Kammersell, Kammersell was charged with transmitting a threatening communication in interstate commerce in violation of 18 U.S.C. $\$ 875(\mathrm{c}){ }^{273}$ Kammersell had logged onto his Internet service provider, America OnLine (AOL), from his home computer in Riverdale, Utah, in order to send a message to his girlfriend in Ogden, Utah. He sent her a bomb threat via "instant message" in hopes that she would be able to leave work early and go on a date with him. ${ }^{274}$ Since AOL's server is based in Virginia, the "instant message" was first autoniatically transmitted to Virginia, then instantly sent back to his girlfriend in Ogden, Utah. ${ }^{275}$ Kammersell argued that, because so many local telephone and internet communications are first routed out of state, federal jurisdiction would cover almost any communication made by telephone or modem if the court sustained the application of the statute to his activities. ${ }^{276}$ Nevertheless, the Tenth Circuit upheld the statute. ${ }^{277}$ Thus, the use of the jurisdictional element in the statute at issue in Kammersell leads to absurd results, just as it did in the carjacking statute: anyone who wants to send bomb threats to his neighbors must avoid using the phone, Internet, or mails in order to avoid federal prosecution - that is, of course, unless he lives in Virginia, where he might be able to just send an AOL instant message without transmitting anything across state lines.

\section{$\mathrm{V}$ \\ REWORKING THE JURISDICTIONAL ELEMENT}

As illustrated above, lower courts faced with Lopez- and Morrisonbased challenges to federal statutes have tended to presume that the presence of a jurisdictional element nivokes an "as applied" challenge to a facially valid statute under the channels and instrumentalities prongs. They

272. Lopez, 514 U.S. at 561-62.

273. 196 F.3d 1137 (10th Cir. 1999), cert. denied, 530 U.S. 1231 (2000). Section 875(c) crimmalizes transmission in interstate or foreign commerce of any communication threatening to injure or kidnap another person. 18 U.S.C. $\$ 875$ (c).

274. Kammersell, 196 F.3d at 1138.

275. Id.

276. Id. at 1139 .

277. Id. The transmission in interstate commerce requirement is the jurisdictional element. 
have then applied those prongs leniently by presuming that the crossing of state lines ensures a sufficient connection to interstate commerce. To explain further, if a statute does not contain a jurisdictional element, a reviewing court must determine if a statute is facially valid. If a statute does contain a jurisdictional element asserting Congress's authority, then the statute is presumed to be facially valid, and a reviewing court must determine whether the statute is valid "as applied" to each particular case. The problem, however, is that when courts allow any line crossing (which is generally easy for the government to prove) to satisfy the jurisdictional element and thus ensure a sufficient connection to interstate commerce, the statutes undergo no additional Commerce Clause analysis. In sum, constitutionality is essentially assumed both facially and as applied.

The viability of federalism depends on limiting the use of the Commerce Clause power to persons, goods, and activities that have a real connection to interstate commerce. However, the method that the courts use to analyze the statutes avoids scrutiny of the key issue: whether a concrete connection to interstate commerce exists. Instead, when the statute contains a jurisdictional element, it is presumed facially valid and valid as applied when the government can prove a line crossing. This result occurs even when the line crossing has nothing to do with the regulated activitywhen it is temporally remote from the regulated activity; ${ }^{278}$ when the regulated activity, absent the random line crossing, has absolutely no connection to interstate commerce; ${ }^{279}$ and even when the harm being regulated is in no way connected with the line crossing. ${ }^{280}$ Furthermore, since the jurisdictional element can include the "affecting commerce" language, courts sometimes even view the line crossing as creating a presumption that there is a substantial effect on interstate commerce. Thus, the Court should impose an additional nexus requirement on the jurisdictional element to rein in its use so that constitutionally questionable statutes are subject to at least some judicial scrutiny. Granted, there are some rationales under the channels and instrumentalities prongs that are entirely separate from the jurisdictional element, like the diseased-cattle rationale, and yet have the potential to be applied without limits. However, the Court has evinced its intention not to entirely reexamine the channels and instrumentalities prongs. Thus, in order for the Commerce Clause to be truly limited by federalism principles, the Court should first start with the smaller task of revising its current approach to the jurisdictional element.

278. E.g., United States v. Napier, 233 F.3d 394 (6th Cir. 2000).

279. E.g., United States v. Kirk, 70 F.3d 791 (5th Cir. 1995), aff'd en banc, No. 94-50472, 1997 U.S. App. LEX1S 12670 (1997).

280. E.g., United States v. Milton, 966 F. Supp. 1038 (D. Kan. 1997). 


\section{A. Unworkable Solutions}

Revising the jurisdictional element is not, of course, the only solution. Many commentators critical of the Court's current Commerce Clause jurisprudence have proposed drastic reforms, which I review in this Section. For the most part, the solutions proposed by these scholars are limited by the Court's unwillingness to completely revamp its Commerce Clause jurisprudence. Thus, in this Section, I also discuss some obvious and less drastic solutions that will bring us at least a few steps closer to an original understanding of Congress's Commerce Clause power. First, I discuss a time-nexus requirement, which would require the line crossing to occur within a certain amount of time of the regnlated activity. Second, I discuss a commerce-nexus requirement, which would require that the line crossing be related to commerce or a commercial activity. Third, I discuss a causation-nexus requirement, which would require that the line crossing actually cause the harm that Congress is trying to prevent.

While each of these solutions has its benefits, I ultimately conclude, however, that each presents serious definitional problems. I then discuss my proposed solution, a purpose-nexus requirement, which would require that the line crossing support Congress's purpose in enacting the statute and, further, that the purpose in enacting the statute is a proper one under the Commerce Clause power. While none of these solutions are infallible, I argue that the purpose-nexus requirement is the most workable because the Court is certainly capable of divining many of the Framers' purposes for enacting the Commerce Clause in the first place. Tying a regulation to these purposes thus ensures that Congress is within the boundaries of an original understanding of its Commerce Clause power.

\section{Drastic Reforms}

Criticism of the Court's Commerce Clause jurisprudence is not new, and several commentators have proposed reforms to the Court's Commerce Clause analysis. This subsection addresses the more drastic of those proposed reforms. Richard Epstein and Raoul Berger have both advocated the approach taken by Justice Thomas in Lopez that the Court needs to reroot its Commerce Clause jurisprudence in an original understanding of the Commerce Clause. ${ }^{281}$ Under such an approach, Congress's Commerce Clause power would be closely linked with interstate trade rather than economic activities im general. ${ }^{282}$ Although courts should atteinpt to firmly root their interpretation of Congress's Commerce Clause power in the text and history of the Constitution to the greatest extent possible, this approach presents two primary problems. The first, as mentioned previously,

281. See Lopez, 514 U.S. at 584-602 (Thomas, J., concurring); Berger, supra note 14; Epstein, supra note 14.

282. E.g., Epstein, supra note 14, at 1389. 
involves ambiguity regarding what constitutes commerce "among the several States." 283 Justice Thomas, Epstein, and Berger would likely limit this category to interstate transactions. ${ }^{284}$ However, this proposed solution leads to a second, and more important problem: limiting Congress's Commerce Clause power to interstate transactions would force the Court to overrule nearly every case involving Congress's Commerce Clause power in the latter half of the twentieth century, likely causing disruption not only to the United States' nationally integrated economy but also to important civil rights advances made during the past fifty years. Thus, even if the Court decides to reexamine the channels and instrumentalities prongs of Congress's Commerce Clause power and agrees, in theory, with Justice Thomas's view, it is unlikely to enact such a monumental change to the scope of Congress's power. ${ }^{285}$

Donald Regan takes a very different approach. He criticizes the Supreme Court's Commerce Clause jurisprudence for being too formalistic and for not offering any tangible factors for determining what should be the province of the states and what should be the province of the federal government. ${ }^{286}$ Instead, Regan proposes a two-prong test that a regulation must satisfy in order to pass constitutional review. First, the regulation must be in the "general interest[s] of the union." 287 Second, states must be "separately incompetent" to handle the problem themselves. ${ }^{288}$ Regan's approach does not, however, solve the problem it tries to correct. Formal distinctions, such as what are direct versus indirect effects, may be hard to apply at times, but determining what is "in the general interests of the union" is likely to be just as difficult, even though it is arguably a less formalistic test. Further, in the absence of precedent, such a vague test is likely to undermine some of the federalism principles that the Court enunciated in Lopez and Morrison. ${ }^{289}$ Two purposes of maintaining a dual

283. See supra Part II, at $12-\mathrm{I} 3$.

284. See generally Lopez, 514 U.S. at 584-602; Berger, supra note 14; Epstein, supra note 14.

285. The Court has previously questioned the constitutional underpinnings of an earlier decision but then decided to refrain from overruling that decision because of principles of stare decisis and reliance. See Planned Parenthood v. Casey, 505 U.S. 833, 845 (1992) (considering the scope of Roe $v$. Wade, 410 U.S. 113 (1973)).

286. See Regan, supra note 14, at 554 ("On the one hand, we have a collection of doctrinal rules that, if we take them seriously, allow Congress to do anything it wants under the commerce power. On the other hand, we continue to pay lip service to the idea that Congress's power is limited.").

287. Id. at 570 .

288. Id.

289. The national crisis surrounding the September 11, 2001 terrorist attacks presents a prime example of this problem. While no one would argue that it is not in the general interests of the union to protect American citizens from further terrorist attacks, determining exactly which implementations of those protections are in the "general interests of the union" is subject to various interpretations. While some citizens may be willing to give up certain civil liberties-in the interests of the union-in light of the threat of further terrorist attacks, should that threat significantly dissipate, such a forfeiting of civil liberties might no longer seem to be in the "interests of the union." Would that mean that the law, while constitutional at an earlier time, would be unconstitutional once the threats had subsided? 
system of government are to satisfy diverse preferences and to provide a two-tiered system for securing citizens' liberties. A "general interests of the union" test might undermine rather than protect federalism by imposing policies that thwart not only many of those diverse preferences but also the protection of liberties (because citizens threatened by the imposition of the will of a national majority would not be able to resort to their state governments for protection). Under Regan's approach, Congress might still conceivably be able to decide that it is in the general interests of the union to ban gay marriages, something no state could do on its own. Regan's test does not include a limiting factor that would curb legislation like this that has little if anything to do with imterstate commerce. Thus, although Regan's suggestion that we look to the "general interests of the union" is plausibly connected with one of the purposes behind the Commerce Clause power, the Court needs to further interpret that language. Otherwise it will be subject to interpretations as broad and unwieldy as some of the interpretations of "interstate commerce."

Professors Grant Nelson and Robert Pushaw propose an approach that is both more workable and truer to the history and text of the Constitution than Regan's approach. ${ }^{290}$ Nelson and Pushaw agree with Justice Thomas that modern Commerce Clause jurisprudence should comport with the text and history of the Commerce Clause but propose adopting a test that would not require the Court to completely overrule all modern Commerce Clause jurisprudence. ${ }^{291}$ Their proposed test supports the results of most of the Court's modern Commerce Clause cases but rejects the reasoning in those cases. ${ }^{292}$

Under Nelson and Pushaw's approach, the Commerce Clause has two requirements. First, Congress must regulate "commerce." Acknowledging criticisms that it is impossible for courts to define "commerce" with any precision, ${ }^{293}$ Nelson and Pushaw undertake a linguistic and historical study to produce a definition of commerce that includes three categories: (1) buymg and selling goods, the production of those goods, and the "incidents of that production;" (2) the "compensated provision of services," such as labor and banking; and (3) "the means by which commerce is transacted," such as contracts and letters of credit. ${ }^{294}$ Furthermore, Nelson and Pushaw reject the Court's channels and instrumentalities theories entirely, limiting their definition of commerce to include only transportation that is "undertaken for business purposes or provided by a common carrier."2295

290. See generally Barnett, supra note 55.

291. Nelson \& Pushaw, supra note 55, at 107.

292. Id. at 7 .

293. Id. at n.451.

294. Id. at 108.

295. Id. at 109. 
Second, the regulation must "implicate[] commerce in more than one state," ${ }^{296}$ which Nelson and Pushaw define as having "commercial effects in more than one state." ${ }^{297}$ However, since Nelson and Pushaw acknowledge that most commerce does have some commercial effects in more than one state given our integrated economy, they propose that courts should view this prong of the test leniently, asking only whether "Congress has provided a 'rational basis' for its conclusion about such a commercial impact." 298

This approach does present a workable definition of commerce, though one not without problems. For instance, Nelson and Pushaw require that Congress must regulate "commerce," a similar requirement to that imposed by the Court under the substantial-effects prong in Lopez. ${ }^{299}$ Courts have sidestepped this Lopez requirement, however, by defining the "regulated activity" rather broadly. For instance, in Rancho Viejo $v$. Norton, ${ }^{300}$ the District Court for the District of Columbia considered a constitutional challenge to a provision of the Endangered Species Act of 1973 which forbade any person to "take any [endangered or threatened] species within the United States or the territorial sea of the United States." 301 The statute defined "take" as to "harass, harm, pursue, hunt, shoot, wound, kill, trap, capture, or collect, or to attempt to engage in any such conduct." ${ }^{302}$ In Rancho Viejo, the plaintiff was a real estate development company that was attempting to construct homes on some of its property.$^{303}$ In one of the construction areas, Rancho Viejo built a fence, which the U.S. Fish and Wildlife Service determined constituted an "illegal take" of the arroyo toad under the Endangered Species Act. ${ }^{304}$ Though the regulated activity in question would seem to be the "take" of the arroyo toad, as that is specifically what Congress had forbidden, the court defined the regulated activity in broader terms. Since in this case the regulation forbidding a "take" of arroyo toads would interfere with the building of homes, the court defined the home building, rather than the take, to be the regulated activity and thus properly within Congress's Commerce Clause power under the substantialeffects prong. ${ }^{305}$ Under this broad view of what constitutes the regulated

296. Id. at 107.

297. Id. at 110 .

298. Id. at 111. Since Nelson and Pushaw envision a speetrum of commercial effects, some warrant federal regulation and some not, they view this prong more as a "question of policy, not constitutional authority," justifying their proposed deference to congressional determinations. Id. at 110 .

299. Id. at 110; Lopez, 514 U.S. at 561 (noting that the GFSZA "is a criminal statute that by its terms has nothing to do with 'commerce' or any sort of economic enterprise").

300. No. 1:00-CV-02798, 2001 U.S. Dist. LEXIS 16444 (D.D.C. Aug. 20, 2001).

301. 16 U.S.C. $\S 1538(\mathrm{a})(1)(\mathrm{B})(2000)$.

302. 16 U.S.C. $\$ 1532(19)(2000)$.

303. 2001 U.S. Dist. LEXIS 16444 at *1-2.

304. Id. at $* 5-6$.

305. Id. at $* 21$. 
activity (and thus what must be considered "commerce" or commercial in nature), Nelson and Pushaw's test might not impose any real limits.

Moreover, Nelson and Pushaw's lenient standard for enforcing the second prong hearkens back to the pre-Lopez substantial-effects test. ${ }^{306}$ Nelson and Pushaw require not only that Congress regulate "commerce," but also that the regulation implicate more than one state; otherwise the Framers might as well have written the Constitution to simply give Congress the power to regulate all commerce. But, as the government's arguments in Lopez demonstrated, almost everything will "implicate" and have a commercial effect on more than one state if viewed at a certain level of generality. If we defer to congressional findings that something implicates more than one state, we would be allowing Congress, as has happened under the substantial-effects prong, to define the scope of its own power as long as it could come up with a chain of causation that in the end links the regulation and soine interstate effects. Since my selling a stick of gum for twenty-five cents to my sister would constitute "commerce" under this approach, as long as Congress could provide a "rational basis" for finding that the sale had a commercial impact on another state, Congress could regulate it. This logic seems almost as absurd as allowing Congress to regulate that sale simply because the stick of gum was manufactured in another state. Thus, Nelson and Pushaw's approach might not remedy the above-discussed probleins created by the limitless jurisdictional element. ${ }^{307}$

The most difficult hurdle to revitalizing the Commerce Clause as a limit on federal power is, of course, that Lopez and Morrison evinced not even a hint of willingness to completely reexamine and transform the Court's current Commerce Clause jurisprudence. The Court's reluctance may reflect the practical concerns I noted earlier: that major reforms would require the Court to overrule half a century of Commerce Clause precedents, thereby causing disruption to the economy and inportant civil rights advances made in the past fifty years. Given these potential consequences of drastic reforms, this Comment proposes a more limited revision of Commerce Clause jurisprudence that focuses only on the jurisdictional element. Simply stated, this Comment proposes that the Court should, as a first step in protecting federalism after Lopez and Morrison, constrain the use of the jurisdictional elenient by requiring a closer counection to

306. See supra Part II.A.

307. For example, when Nelson and Pushaw apply their approach to Lopez, they reach the same result as the Supreme Court did because firearm possession in school zones is not a commercial activity. Nelson \& Pushaw, supra note 55, at 130-31. In contrast, under their approach they would uphold the Freedom of Access to Clinic Entrances Act because "[a]bortion entails the sale of a service, and the buildings where these services are provided are commercial establishments." See id. at 150 . It is not inconceivable, however, for some to characterize schools as entailing the sale of services, as although there is no direct payment (except in the case of private schools), citizens pay for the services through local taxes. Under this characterization, it is possible that the Nelson and Pushaw approach would not invalidate the GFSZA. 
interstate commerce itself, just as the Court attempted to rein in the substantial-effects prong by requiring a closer connection to commerce. This practical solution should help protect federalism and is one step closer to rerooting the Commerce Clause in an understanding more true to the constitutional provision as it was enacted. Further, it should not significantly disrupt the economy or society, and it should not require the Court to explicitly overrule any aspect of Lopez or Morrison.

\section{Time-Nexus Requirement}

The most obvious limitation the Court could impose on the channels and instrumentalities prongs is a time-nexus requirement. Under this approach, a jurisdictional element would continue to require that a regulated person, good, or activity be "in or affecting commerce." However, in contrast to the status quo, only a subset of line crossings connected with the regulated person, good, or activity would be sufficient to satisfy the statutory language. Specifically, the time-nexus requirement would allow Congress to regulate activities based on a line crossing only when the line crossing occurred within a certain amount of time of the regnlated activity. For example, under a time-nexus approach, Congress would have to redraw the federal carjacking statute to require the prosecutor to prove that the carjacked vehicle had traveled across state lines within a specified period of time.

If we assume, for the moment, that transporting a vehicle that is soon to be carjacked, or has been recently carjacked, across state lines somehow implicates interstate commerce, then the time nexus would solve some of the problems that the Court has encountered in placing limits on Congress's Commerce Clause power under the channels and instrumentalities prongs. For instance, in United States v. Gamble, the court acquitted the defendant after the prosecution failed to prove that the hijacked car had ever crossed state lines. ${ }^{308}$ However, the vehicle that the defendant in Gamble allegedly carjacked probably had the same trivial connection to interstate commerce as a vehicle that had provably crossed state lines ten years earlier. Nevertheless, if Gamble had carjacked the latter vehicle, the prosecution would have prevailed. With a time nexus, the court could have avoided this type of absurdity. A time-nexus approach would treat the two vehicles similarly because both had such a remote connection to interstate commerce-line crossing or not-that congressional regulation would not be justified.

Similarly, a time nexus would ensure that Congress could not add formalistic fixes to statutes that fail under the substantial-effects prong by including a jurisdictional element, as Congress did when it revised the 
GFSZA. Instead, a time nexus would require that the perpetrator carry the firearm across state lines and into a school zone within a specified period of time, or carry it into a school zone and then shortly thereafter cross state lines, in order to implicate federal jurisdiction.

Thus, assuming that a simple line crossing actually implicates interstate commerce in some way, a time-nexus requirement could potentially ensure a closer connection between interstate commerce and the regulated activity and could potentially limit Congress's power to regulate any person or good that has ever crossed state lines. However, the assumption embedded in these conclusions looms large. A time nexus alone, though it would ensure a closer connection to interstate commerce than is currently required to sustain congressional jurisdiction, would not ensure that Congress's jurisdiction is consistent with a more restrictive understanding of the Commerce Clause. For instance, even if we were to require Congress to reenact the GFSZA with a time nexus requiring that the gun being transported into a school zone had crossed state lines within the past ten days, such a revision does not seem to bring the statute anymore within Congress's Commerce Clause power than the original GFSZA. Many would argue that activities in a local school zone should be regulated by the state and local law enforcement. Thus, a time nexus in a statute like the GFSZA may increase the likelihood that the regulated activity implicates interstate commerce (perhaps because the perpetrator bought the gun in another state with less stringent gun controls and then had it shipped to his own state), but a time nexus does not necessarily ensure that Congress is acting within the proper scope of the Commerce Clause power.

Thus, in practice, a time-nexus requirement may not prove very useful for limiting the scope of congressional power under either the channels or the instrumentalities prong. For instance, even with the imposition of a strict time-nexus requirement, Congress could still exercise a general police power by regulating anything that passes through the channels of interstate commerce, as long as it defines the person or good that passes through the channels of commerce as the evil it is regulating. For instance, a time nexus would not limit Congress's ability to regulate gay marriages by forbidding people who have entered into a gay marriage from passing through the channels of interstate commerce. As in the Lottery Case, the Court can characterize almost anything as "evil," compare it to diseased cattle spreading infirmity through the channels of commerce, and then uphold the prohibition on its movement through the channels of commerce. ${ }^{309}$

309. Congress has already passed the Defense of Marriage Act (DOMA), Pub. L. No. 104-199, 110 Stat. 2419 (1996), which permits a state to disregard any act, public record, or judicial proceeding of another state that recognizes rights or claims arising from a relationship between people of the same sex. Although DOMA gives States the right to choose whether or not to recognize same-sex marriages, its limited scope does not necessarily mean that Congress does not have the power to regulate same-sex marriages. 
Similarly, a time-nexus requirement might still allow expansive regulation under the instrumentalities prong, as long as Congress is careful in its drafting. For instance, Congress could still federally criminalize any activity that involved an interstate highway, the Internet, the mails, a railway, or any other instrumentality of commerce during the commission of the crime. As long as "commission of the crime" is defined liberally enough, it would not likely be hard to prove that the perpetrator drove on an interstate highway or used a telephone connected to interstate wires during the "commission of the crime." Statutes such as the felon-in-possession statute, which is based on simple possession alone (e.g., where Congress might hypothetically punish "possession of a firearm by a felon using any instrumentality of commerce"), would make the prosecutor's task even easier unless the felon locked himself in his house and avoided all roadways, highways, modems, and even mails.

Even beyond these limitations on the usefulness of a time nexus, bigger problems arise in trying to define the parameters of the nexus. It is unclear where the Court would look, constitutionally or historically, ${ }^{310}$ to determine a proper time nexus for each regulated activity, especially as the time-nexus requirement would likely differ substantially depending on the person, good, or activity being regulated. Setting these precise standards seems more like a legislative task than a judicial one.

\section{Commerce-Nexus Requirement}

Alternatively, the Court could require that the line crossing (or prohibition on line crossing under the channels prong) be explicitly related to commerce or a commercial activity. For example, with a commerce-nexus requirement, the jurisdictional element in the felon-in-possession statute ("in or affecting commerce") could only be proved by a showing that the firearm crossed state lines in connection with a commercial transaction, for instance via a sale transacted across state lines. This would address the problem Justice Fuller pointed out in his dissent in the Lottery Case when

310. In early Commerce Clause cases, the Supreme Court utilized a chain-of-commerce-like rationale that imposed an implicit time nexus, but the Court never clearly articulated the boundaries of the time nexus. For instance, in The Daniel Ball, 77 U.S. (10 Wall.) 557 (1870), the Court upheld an application of the Act of July 7, 1838, which regulated the transportation of merchandise or passengers upon the navigable waters of the United States without a proper license, to the Daniel Ball, a steam vessel engaged in navigation of waters solely within the state of Michigan. Id. at 557. The Court based its holding on the fact that the Daniel Ball was transporting merchandise that had recently come from another state, or was soon destined for other states after its transportation on the Daniel Ball. See id. at 565. The Court supported its holding by pointing to the close temporal nexus between the line crossing and the passage on the Daniel Ball. Id. at 566. However, the Court did not reach the question of whether the statute would still apply if the Daniel Ball carried only merchandise that had been shipped across state lines months or even years earlier. 
he noted that under the majority's opinion, "an invitation to dine" shipped across state lines would constitute interstate commerce. ${ }^{311}$

Moreover, a commerce nexus would, in part, remedy the confusion discussed in Part IV regarding the jurisdictional element's role in the analysis by bringing the substantial-effects prong and the channels and instrumentalities prongs closer together. Under the substantial-effects prong, Congress must prove that the regulated activity is commercial in nature and has a substantial effect on interstate commerce ${ }^{312}$ To get around the requirement that the activity needs to be commercial in nature, courts can simply posit that anything that passes through the channels and instrumentalities of commerce has an effect on commerce and therefore falls within congressional jurisdiction to regulate. However, if Congress exercises its Commerce Clause power to regulate something based on its effect on commerce, that regulation would more properly fall under the substantialeffects prong. To avoid the problem of classifying whether or not the statute covers wholly intrastate activity, a commerce nexus would prevent Congress from regulating intrastate, non-commercial activity (through the use of a jurisdictional element) that would more properly fall under the substantial-effects prong because it does not involve the channels or insirumentalities of commerce in some substantial way.

Imposing a commerce nexus requiring that the line crossing actually implicate interstate commerce to a specific degree is one of the most obvious solutions to curb an otherwise limitless Commerce Clause power. The commerce nexus would work similarly to Nelson and Pushaw's proposed changes and would share some of their shortcomings. ${ }^{313}$ The primary difficulty with imposing such a strict commerce nexus requirement is that the requirenent would, in effect, eliminate the channels and instrumentalities prongs altogether. As I noted earlier, although this result might be consistent with an original understanding of the Commerce Clause, it is highly unlikely that the Court will take such a rapid turn in its jurisprudence. A second problem is that courts can sidestep any definition of "commerce" by defining the regulated activity broadly. Take, again, the Rancho Viejo example: although the statute regulated the taking of certain species, the court defined the regulated activity as hone building, and thus found the activity to be commercial. ${ }^{314}$ Finally, a commerce nexus would pose significant line-drawing problems: courts would be forced to deterinine what constitutes more than a de minimis connection to commerce. However, this determination may not lead to greater protection for federalism. As the reasoning in the Lopez dissent inakes clear, if one piles enough inferences on

311. Champion v. Ames, 188 U.S. 321, 371 (1903).

312. See Lopez, 514 U.S. 549.

313. See supra notes $290-307$ and accompanying text.

314. Rancho Viejo, 2001 U.S. Dist. LEXIS 16444. 
top of each other, almost everything seems to have a connection to commerce. $^{315}$

\section{Causation-Nexus Requirement}

A third possible limitation the Court could impose on the jurisdictional element is a causation nexus. Under this test, the jurisdictional element would sustain the constitutionality of a statute only if the line crossing caused the harm that Congress is trying to prevent. For instance, in enacting the Dyer Act, ${ }^{316}$ Congress was concerned with the increasing number of interstate auto thefts. ${ }^{317}$ Since the stolen cars could be easily transported across state lines and then stripped to sell the parts, it was difficult for individual states to reach the criminal conduct. ${ }^{318}$ Thus, Congress enacted a law criminalizing interstate car thefts, a harm that was directly caused by the line crossings and that state and local authorities could not have remedied individually. ${ }^{319}$

This method presents two primary problems, however. First, defining causation can be a difficult exercise and might present problems similar to those the Court would face in imposing a time-nexus requirement. For instance, under the felon-in-possession statute, ${ }^{320}$ if a firearm has been transported across state lines and eventually falls into the hands of a felon, certainly the line crossing is in some sense a "but-for" cause of that possession. However, at a certain point there will likely have been too many intervening acts to satisfy any theory of proximate causation. The first problem, therefore, is determining where to draw the line.

The second problem is that Congress may be able to avoid this limitation by altering how it defines the harm it is trying to reach. Take, for example again, the hypothesized statute forbidding couples who have entered into a gay marriage from crossing state lines. Congress could first deem gay inarriages "evil," as it did lottery tickets in the Lottery Case. ${ }^{321} \mathrm{Next}$, it could decide that it wants to protect interstate commerce from that evil, since people who have entered into gay inarriages might influence others traveling in interstate commerce. Under this rationale, Congress could decide to prohibit the interstate line crossing of people who have entered into gay marriages. After all, if the harm Congress is trying to protect against is the spreading of the "evil infiuences" of those who have entered into gay marriages to others traveling in interstate commerce, then the line crossing has "caused" the harm and the nexus would be satisfied. Thus, a causation

315. Lopez, 514 U.S. at 615-44 (Breyer, J., dissenting).

316. 18 U.S.C. $\$ 2311$ (2002).

317. 58 CoNG. ReC. H5470, H5471 (Sept. 15, 1919) (remarks of Rep. Dyer).

318. Id.

319. Id.

320. See supra Part V.B.2.

321. See supra notes 118-27 and accompanying text. 
nexus, like a time nexus, still will not remedy the fact that under current Commerce Clause doctrine, Congress still has a general police power to regulate almost any subject.

\section{B. A Workable Solution: A Purpose-Nexus Requirement}

The problems highlighted in the proposals previously discussed lead me to propose a purpose-nexus requirement as the most plausible solution to the jurisdictional-element problem. The Court should impose a purpose nexus that would have two interrelated requirements. First, the inclusion of the jurisdictional element (the line crossing requirement) must support Congress's purposes in enacting the statute. Second, those purposes in enacting the statute must be sanctioned by the Commerce Clause power. ${ }^{322}$ The purpose nexus would ensure that, for instance, under the federal carjacking statute a prosecutor could not satisfy the jurisdictional element by proving that the car's paint or steering wheel had been shipped in interstate commerce without demonstrating (1) that Congress enacted the statute, at least in part, to regulate the interstate transportation of vehicles which either have been carjacked or might be carjacked and which used paint or steering wheels from other states; and (2) that this purpose is a proper one for congressional regulation (in other words, connected to the purposes for giving Congress the Commerce Clause power in the first place).

The purpose nexus would solve most of the problems discussed earlier regarding the lower courts' opinions, ${ }^{323}$ both by limiting statutes that might legitimately fall within Congress's Commerce Clause power but have been too expansively interpreted, and by invalidating statutes that do not fall within Congress's Commerce Clause power at all. For instance, Congress should, as it did in the Dyer Act, be able to reach carjackings where the perpetrator takes the vehicle across state lines, usually in order to sell the parts. However, the purpose nexus would limit Congress to that appropriate purpose. In contrast, a jurisdictional element that required only a line crossing at any time in the car's existence, even years before the carjacking occurred, could not be said to support the proper purposes in enacting the statute: preventing the interstate trade in carjacked vehicles and

322. Purpose requirements have been advocated in different contexts, but this is the first time a purpose requirement has been proposed as a limitation on Congress's use of the jurisdictional element. Harry Litman and Mark Greenberg examined the issue of characterizing Congress's Commerce Clause power from a purpose-based view, as opposed to a subject-based view, and summarized the general argument for imposing a purpose requirement:

The Commerce Power was given to Congress so that it could accomplish specific purposes, such as to provide for uniform standards and to protect the channels of interstate commerce from parochial interference. Why should Congress be able to accomplish purposes other than those for which the power was included in the Constitution?

Harry Litman \& Mark D. Greenberg, Federal Power and Federalism: A Theory of Commerce-Clause Based Regulation of Traditionally State Crimes, 47 CASE W. REs. L. REv, 921, 934-41 (1997).

323. See supra Part IV.B. 
parts. Statutes that do not evince a proper purpose, like the GFSZA, would likely fail altogether. Congress might be able to show that the jurisdictional line crossing required in the statute is reasonably related to the purpose of preventing firearms from being carried through interstate commerce and into school zones, but it is doubtful that the Court would find that this is a purpose sanctioned by an original understanding of the Commerce Clause, or at least not in relation to the regulation of the channels and instrumentalities of commerce.

A purpose nexus would also be more workable than a time nexus because it would produce less arbitrary results and would not force the Court to overrule some important decisions made under the channels and instrumentalities prongs of Congress's Commerce Clause power. For instance, the statute at issue in Southern Railway v. United States ${ }^{324}$ did not hinge on the presence of a jurisdictional element for its constitutionality. Rather, the statute was based on the need to prevent physical injury on the interstate railways, a proper purpose under the Commerce Clause power, and the practical inpossibility of doing so without regulating cars on both intrastate and interstate railways. Nelson and Pushaw suggest that the channels and instrumentalities prongs be eliminated altogether, but the Court has already expressed its unwillingness to do so. Instead, a purpose nexus will ensure that if Congress is relying on a jurisdictional element (and hence its jurisdiction is likely not as clear), a more meaningful review under the channels and instrumentalities prongs will ensue; but if a statute does not contain a jurisdictional element, then the Court's usual Commerce Clause analysis will apply. Thus important decisions such as those upholding the public accommodations provisions of the Civil Rights Act of 1964 would not be put at risk by imposing a purpose nexus because the Court ostensibly decided those cases under the substantial-effects prong and explicitly declined to overrule them in Lopez. ${ }^{325}$

To impose a purpose nexus, we must first in each instance determine what Congress's purpose was in enacting a statute, and then determine for what purposes Congress can properly act under the Commerce Clause to regulate the channels and instrumentalities of commerce (and if the purpose for enacting the statute falls within those purposes) ${ }^{326}$ As to the first determination, an obvious problem arises. The Constitution only requires that both the House of Representatives and the Senate pass the statute, and

324. 222 U.S. 20 (1911).

325. Heart of Atlanta Motel, Inc. v. United States, 379 U.S. 241 (1964); Katzenbach v. McClung, 379 U.S. 294 (1964).

326. In imposing a purpose nexus, it is integral to examine if it is a "proper" purpose for Congress to act upon under the Commerce Clause, as otherwise Congress could simply get around the requirement by defining legislation in terms of purposes totally unrelated to the underlying purposes of giving Congress the Commerce Clause power in the first place. 
that it is presented to the President. ${ }^{327}$ The Constitution does not require that Congress enact formal legislative findings underlying a statute, or set forth its reasons or purpose behind enacting a statute. Thus, often the only way to determine the congressional purpose behind a statute, beyond mere speculation, is to examine the legislative history of the statute. The legislative history, however, is often filled with comments and statements that do not reflect a unanimous or even majority opinion regarding the purposes behind the legislation. Furthermore, some statutes may contam very little legislative history. Of course, the Court could always use regular principles of statutory interpretation, as it often does, to determine the primary purpose behind the legislation by looking to its primary effect.

After ascertaining the primary purpose behind the statute, we must next determine what the proper purposes for Congress to act upon are. The Commerce Clause, unlike the Copyright Clause, ${ }^{328}$ for instance, does not enumerate a specific purpose behind the power. Moreover, putting the indeterminacy of the precise scope of the purposes underlying the enactment of the Commerce Clause aside, restricting Congress's power to enact only regulations that, for instance, protect interstate commerce and prevent states from discriminating against other states might force the Court to invalidate too many statutes passed under Congress's Cominerce Clause power in the latter half of the twentieth century.

Finally, to impose a purpose nexus, the current Court will have to deal with the fact that the Supreme Court has long rejected this purpose-based view, as for example when it upheld Title II of the Civil Rights Act of 1964 as a proper exercise of Congress's Cominerce Clause power. ${ }^{329}$ In Heart of Atlanta Motel, the Court upheld the provision of the Civil Rights Act of 1964 that outlawed discrimination and segregation in public accommodations based on race, color, religion, or national origin, despite the fact that the primary purpose in enacting the statute had nothing to do with protecting interstate commerce. Rather, the statute was enacted in large part to vindicate "the deprivation of personal dignity that surely accompanies denials of equal access to public establishınents." ${ }^{330}$ As long as the regulated conduct fell sufficiently within Congress's Commerce Clause power, the Court found that the social or moral purposes motivating the Act did not affect its constitutionality. ${ }^{331}$

Despite these difficulties, a purpose nexus will still mark a positive step towards an original understanding of the Commerce Clause power by

327. U.S. Const. Art. I, $\S 7, \mathrm{cl} .2$.

328. The Patents and Copyrights Clause allows Congress "[t]o promote the Progress of Science and useful Arts, by securing for limited Times to Authors and Inventors the exclusive Right to their respective Writings and Discoveries." U.S. ConsT. art. I, \$ \&, cl. 8.

329. See Heart of Atlanta, 379 U.S. 241.

330. Id. at 29I-92 (Goldberg, J., concurring).

331. Id. at 256 . 
limiting the presumptions that accompany the inclusion of a jurisdictional element. Arguments about the complete scope of permissible purposes under the Commerce Clause power aside, we can broadly identify some of the underlying purposes behind the enactment of the Commerce Clause power. For instance, the Virginia Resolution set forth specific areas where the Commerce Clause power was required: (1) where the states are severally incompetent; (2) where individual state legislation might interrupt the harmony of the United States; and (3) where the legislated interest affects the general interests of the Union. ${ }^{332}$ Hypothetically accepting these justifications as a starting point (though the Court would obviously need to conduct a detailed inquiry into the enactment of the Commerce Clause power to accurately and precisely identify the underlying purposes), we can see that Congress's power to regulate the channels and instrumentalities of commerce most likely falls within the first two areas. Few would question that it is a permissible purpose for Congress to protect the channels and instrumentalities of interstate commerce from injurious uses, both because they can be used by the states to discriminate against each other, and because the states are severally incompetent to regulate the interstate channels and instrumentalities of commerce. We should limit Congress's ability to use the jurisdictional element to create a presumption of constitutionality to instances where Congress's regulation of the channels and instrumentalities of commerce is motivated by those proper purposes. Though defining the proper purposes for Congress's use of the Commerce Clause power in its entirety would be a difficult task, imposing a purpose nexus requires no such undertaking. Instead, the purpose nexus merely addresses the problem of the limitless use of the jurisdictional element. Currently, there seems to be a presumption of constitutionality if a statute includes a jurisdictional element. Here, the Court would be telling Congress: there are certain identifiable proper purposes that can underlie your regulation of the channels and instrumentalities of commerce, and if you can demonstrate a nexus between the regulation of the line crossing and those proper purposes, the inclusion of a jurisdictional element in a statute will lead to a presumption of constitutionality.

This is not to say that protecting the channels and instrumentalities of interstate commerce from injurious uses is the only proper purpose under which Congress can act under the Commerce Clause. Instead, as previously noted, it merely limits the presumption of constitutionality that the jurisdictional element has enjoyed to instances linked to a proper purpose. If Congress wants to act under other proper purposes under its power, it can still do so, but such statutes will not be presumed to be facially valid and

332. See Douglas W. Kmiec, Rediscovering a Principled Commerce Power, 28 PEPP. L. REv. 547, 561-62 (citing Charles C. Tansill, Records of the Debates in the Federal Convention of I 787 AS REPORTED BY JAMES MADISON (1989)). 
must survive scrutiny under one of the prongs of Congress's Commerce Clause power. Certainly there will be instances where Congress will regulate the channels and instrumentalities of Commerce without utilizing a jurisdictional eleinent, and where a challenge to such regulation would cause a court to scrutinize whether that regulation falls within Congress's Commerce Clause power. The purpose nexus does not change any of that. Take again the felon-in-possession statute as an example. Suppose Congress reenacted the felon-in-possession statute for the purpose of preventing such possession just because it thought possessions of firearms by felons were evil. A court, under a purpose nexus, would likely reject Congress's purpose as improper because Congress was not trying to protect the channels and instrumentalities of interstate commerce from firearms possessed by felons (which itself may need to be supported by a finding, for instance, that such possession caused substantial interstate violence or illegal transactions involving firearms). All this would mean is that Congress could not ensure a statute's constitutionality by simply including the "in or affecting commerce" language in the statute requiring only the showing of a random line crossing. Instead, Congress would have to demonstrate somehow that, for instance, the interest being legislated affects the general interests of the Union because it has a substantial effect on interstate commerce. The point is that Congress would have to draw the connection between the firearm possession and its Commerce Clause power if the statute was challenged (instead of relying on the fact that the gun crossed state lines), and a court would have to undertake a more searching review.

\section{CONCLUSION}

In his separate concurring opinion in Lopez, Justice Thomas noted how far we have strayed from the original understanding of the Commerce Clause. Further, he suggested that the Court should, at a later time, reexamine the substantial-effects prong of Congress's Commerce Clause power in its entirety, or otherwise risk repudiating "our long-held understanding of the limited nature of federal power...."333 Justice Thomas is right. If the Court wants to protect federalism, it must revisit its Commerce Clause jurisprudence. While the Court can check congressional power in other areas, such as the Eleventh Amendment, leaving the Commerce Clause untouched would, even after Lopez and Morrison, still leave Congress with considerable powers to regulate almost anything. However, revisiting the substantial-effects prong alone is insufficient. In fact, as it now stands, the substantial-effects prong is the only prong of Congress's Commerce Clause power that actually imposes some limitations, as it is the only prong that 
requires the regulated activity to be linked to commerce, and commerce is the basis of the original grant of power to Congress. The Court should require that there be essential links to commerce in the channels and instrumentalities prongs if it wants Lopez and Morrison to have any lasting impact.

Moreover, limiting the substantial-effects prong will have little practical effect given the manner in which lower courts have interpreted statutes as falling under the channels and instrumentalities prongs even when they seem to fit under the substantial-effects prong. When the Court initially interpreted the Commerce Clause, there was a distinction between each of the prongs of Congress's Commerce Clause power. Now, the prongs are intimately intertwined. Often a regulation of an intrastate activity involves, in some remote way, the channels or instrumentalities of commerce. Furthermore, activities that substantially affect interstate commerce often involve the passage through the channels of interstate commerce, or the use of the instrumentalities of interstate commerce, and sometimes the substantial effect is a product of the passage itself. With this in mind, the Court must recognize that to protect federalism, it must limit more than the substantial-effects prong of Congress's Commerce Clause power. Otherwise courts can, and have, simply recharacterized activities as falling within the limitless channels and instrumentalities prongs.

While the best method to enforce federalism limits on Congress might be to get rid of all three prongs altogether, the Court would be unwilling to do that. Since the Court has also indicated an unwillingness to reexamine the channels and instrumentalities prongs, it is likely that any proposed solution will still leave Congress with the ability to regnlate unuch more expansively than the Framers intended. Liniting the jurisdictional element is the first step towards achieving an original understanding of the Commerce Clause power because it will force courts to more closely examine statutes, regardless of what prong they fall under, rather than rubber stamping every statute that contains a jurisdictional element.

Today, almost every conceivable regnlation will involve either a person or good that has, at some point, traveled in interstate commerce. This remote linkage should not, however, translate into the presumption that every person or good has enough of an effect on interstate commerce, or is enough of a part of interstate commerce, to justify congressional regulation. In the end, Lopez and Morrison have not been revolutions or evolutions. They have not brought forth a significant change in the balance of power between the federal government and the states, and their underpinnings might fall to the wayside in the wake of the September 11,2001 terrorist attacks and the corresponding expansion of federal power. But while the Framers might not have specifically envisioned what the future might hold - that the country and economy would grow as it did, or that the 
United States would face the national crises that it has, both in wars abroad and in being attacked upon its own soil-they still built the Constitution upon a framework that could respond to such developments. Thus, though in everyday life protecting federalism might not appear to be a primary concern, in order to ensure that the federal government responds to new developments within the confines of its Constitutional powers, the Court needs to step in once again and reexamine its Commerce Clause jurisprudence. 
